\title{
Nutritional Efficiency and Nutrient Acumulation of Maize Cultivated in Soils With High Al-KCl Content
}

\author{
Gabriel Octávio de Mello Cunha ${ }^{1}$, Jaime Antonio de Almeida ${ }^{1}$, Clovis Arruda Souza ${ }^{1} \&$ Paulo Roberto Ernani ${ }^{1}$ \\ ${ }^{1}$ Santa Catrina State University, Lages, Santa Catarina, Brazil \\ Correspondence: Gabriel Octávio de Mello Cunha, Santa Catarina State University, Lages, Santa Catarina, \\ Brazil. Tel: 55-499-9820-5999. E-mail: gabriel.cunha4@gmail.com
}

Received: April 26, 2019

doi:10.5539/jas.v11n16p107
Accepted: July 22, $2019 \quad$ Online Published: September 30, 2019

URL: https://doi.org/10.5539/jas.v11n16p107

\begin{abstract}
Most Brazilian soils are weathered and acidic, generally with exchangeable aluminum levels toxic to plants. Aluminum content can exceed $10 \mathrm{cmol}_{\mathrm{c}} \mathrm{kg}^{-1}$ in certain soils, but does not interfere in plant nutrient absorption, transport and accumulation. This study aimed to assess whether the high aluminum levels extracted with 1 mol $\mathrm{L}^{-1} \mathrm{KCl}$ solution affect the nutritional efficiency of maize plants grown in acidic soils in areas of Brazilian states (AC: profile 9, PE, SC and RS) never before cultivated. To that end, two greenhouse experiments were performed (soybean: 45 days and maize: 60 days) with increasing levels of lime $(0 ; 25 ; 50$ and $100 \% \mathrm{H}+\mathrm{Al}$ content). After the experiments and collection, chemical analyses were conducted to characterize the soils and determine the chemical composition of the maize plants. The Al levels did not interfere in maize plants, nutrient absorption, transport, use or accumulation in AC9 and Rosario do Sul (RS) soils, but did affect those cultivated in PE, BR and $\mathrm{CB}$ soils in treatments without lime. The absence of Al toxicity is related to the increased concentration and activity of basic cations and $\mathrm{P}$ in the soil solution.
\end{abstract}

Keywords: acidic soils, aluminum toxicity, soil aluminum, Zea mays

\section{Introduction}

The acidity of most Brazilian soils, especially in subsurface horizons (B), limits establishing and developing production systems for a substantial number of crops (Caires et al., 2008). This may be due to toxic $\mathrm{Al}$ and $\mathrm{Mn}$ concentrations (Bojórquez-Quintal et al., 2017; Tandzi et al., 2018), low exchangeable $\mathrm{Ca}^{2+}$ and $\mathrm{Mg}^{2+}$ levels, and low sum of bases $(\mathrm{S})$, base saturation $(\mathrm{V} \%)$, and $\mathrm{P}$, unfavorable soil properties for growing most crops (Yang et al., 2013; Maluf et al., 2018). However, some soils contain aluminum levels extracted with $1 \mathrm{~mol} \mathrm{~L}^{-1} \mathrm{KCl}$ (Al-KCl) solution exceeding $10 \mathrm{cmol}_{\mathrm{c}} \mathrm{kg}^{-1}$, where plants exhibit no signs of $\mathrm{Al}^{3+}$ toxicity and obtain satisfactory yields. Even when low doses of soil amendments are used, plant yield is satisfactory, demonstrating that not all the $\mathrm{Al}$ deemed exchangeable in soil chemical analysis is in fact toxic to plants (Wadt, 2002; Cunha et al., 2018a, 2018b). On the other hand, most acidic Brazilian soils respond to liming, which is widely used to raise soil $\mathrm{pH}$, sum of bases, base saturation and nutrient availability in the soil solution, thereby enhancing plant nutritional efficiency, providing $\mathrm{Ca}^{2+}$ and $\mathrm{Mg}^{2+}$, neutralizing $\mathrm{Al}^{3+}$ and decreasing $\mathrm{Al}^{3+}$ saturation (Joris et al., 2013; Rutkowska et al., 2015; Cunha et al., 2018a, 2018b).

As soil $\mathrm{pH}$ declines, $\mathrm{Al}^{3+}$ acivity rises in the soil solution, exacerbating the harmful effects on crops (Rutkowska et al., 2015). The most apparent symptoms of Al toxicity are thickened and shortened roots, thereby reducing water and nutrient absorption, leading to poor plant development (Horst et al., 2010; De souza et al., 2016). Al toxicity and low basic cation levels can be resolved by plant breeding and/or soil management techniques (Joris et al., 2013). Liming is the most commonly used management practiceand involves neutralizing $\mathrm{H}^{+}$and $\mathrm{Al}^{3+}$ ions, thereby promoting an increase in $\mathrm{pH}, \mathrm{S}$ and $\mathrm{V} \%$. This makes nutrients more readily available, providing $\mathrm{Ca}^{2+}$ and $\mathrm{Mg}^{2+}$, promoting aluminum precipitation and reducing soil aluminum saturation (Rastija et al., 2014; Adisu et al., 2019). Nutrient availability is the rate at which nutrients are carried to the root surface and the ability of the plant to absorb them (Horn et al., 2006). In other words, it is the release of nutrients from the solid phase to the soil solution, and their transport to the root surface until they are absorbed by the plant (Fageria \& Moreira, 2011; Sathiyavani et al., 2017). Other important mechanisms for plants are related to nutritional efficiency, which directly affects the yield of major crops and is linked to plant nutritional status (Amaral et al., 2011; Carvalho et al., 2012). Nutritional efficiency is associated with absorption efficiency (AE) indices, defined as the relation 
between shoot nutrient content $\left(\mathrm{NC}_{\mathrm{sh}}\right)$ and root dry weight $(\mathrm{RDW})$, demonstrating plant's ability to extract nutrients from the soil, which differs among species (Swiader et al., 1994; Fageria \& Moreira, 2011; Sathiyavani et al., 2017). Some species have an extensive root system while others have high uptake per unit of root length, that is, a high nutrient uptake rate (Tomaz et al., 2009). Transport efficiency (TE) is defined as the relation between total shoot nutrient content $\left(\mathrm{TNC}_{\mathrm{SH}}\right)$ and total plant nutrient content $\left(\mathrm{TNC}_{\mathrm{P}}\right)$ multiplied by $100(\mathrm{Li}$ et al., 1991) and indicates the plant's ability to transport nutrients from the root to the shoot. Use efficiency (UE) is the relation between total dry weight (TDW) squared and $\mathrm{TNC}_{\mathrm{P}}$, and shows the plant's ability to convert the absorbed nutrient into TDW (Siddiqi \& Glass, 1981; Amaral et al., 2011).

The aim of this study was to assess whether high $\mathrm{Al}$ levels extraced different Brazilian soils with $1 \mathrm{~mol} \mathrm{~L}^{-1} \mathrm{KCl}$ $(\mathrm{Al}-\mathrm{KCl})$ solution affect the absorption, transport, use and accumulation of $\mathrm{N}, \mathrm{P}, \mathrm{K}, \mathrm{Ca}, \mathrm{Mg}$ and $\mathrm{Al}$ by greenhouse-grown maize plants, in addition to determining why some plants exhibit $\mathrm{Al}^{3+}$ toxicity and others do not.

\section{Method}

The study was conducted with subsurface horizon (B) samples of five soils. All were collected in areas never cultivated, in the same places where they had previously been described and the majority had Al-KCl levels of more than $4 \mathrm{cmol}_{\mathrm{c}} \mathrm{kg}^{-1}$ (Table 1). Samples of the B horizon were used because of the lower organic matter (OM) in relation to the surface horizon, since it could influence the results by forming organic complexes with Al. Based on the mineralogical and chemical differences, the soils were divided into two groups: smectites with high levels of exchangeable $\mathrm{Al}^{3+}, \mathrm{Ca}^{2+}$ and $\mathrm{Mg}^{2}$, represented by AC9 (PVAal), from Acre state and Rosário do Sul (PBACal) in Rio Grande do Sul (RS) state; smectites with kaolinite containing high Al levels and low exchangeable $\mathrm{Ca}^{2+}$ and $\mathrm{Mg}^{2+}$ concentrations, represented by PE (PVAal) from Pernambuco state and BR (CHal) from Santa Catarina (SC) state. CB (NB), another soil from Santa Catarina, was used as reference, for being more weathered, and exhibiting kaolinite minerology and lower exchangeable $\mathrm{Al}-\mathrm{KCl}, \mathrm{Ca}^{2+}$ and $\mathrm{Mg}^{2+}$ content. Further details of the results of these analyzes can be verified in Cunha et al. (2014) and Cunha et al. (2018a, 2018b).

Table 1. Classification, chemical (before soil incubation and greenhouse experiments) and physical properties of soils collected under natural conditions in different Brazilian regions

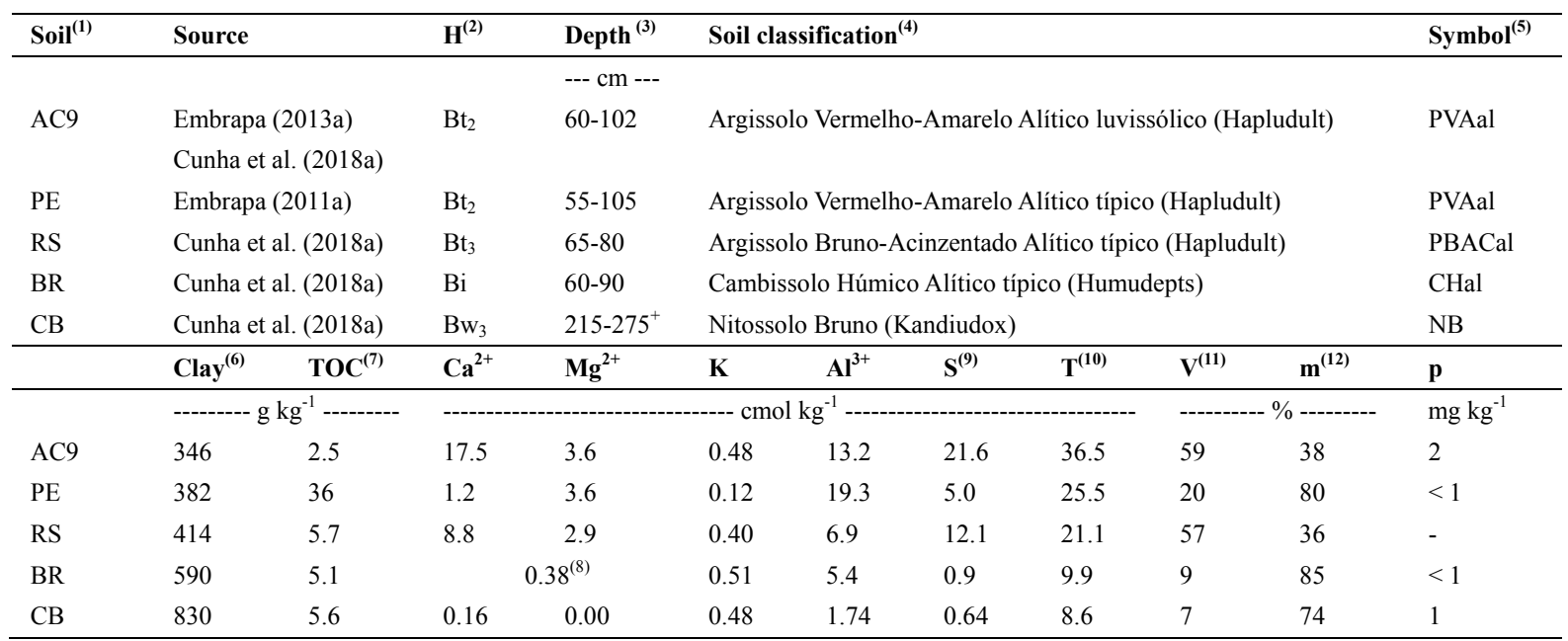

Note. AC9: collected in Tarauacá in Acre state, Profile 9; PE: collected in Ipojuca, Pernambuco state; RS: collected in Rosário do Sul, Rio Grande do Sul (RS) state; BR: collected in Bom Retiro, Santa Catarina (SC) state; CB: collected in Curitibanos, SC; ${ }^{(2)}$ Horizons collected; ${ }^{(3)}$ Soil collection layer; ${ }^{(4,5)}$ Classified according to the Brazilian Soil Classification System (Embrapa, 2013b); ${ }^{(6)}$ Clay fraction below $0.02 \mathrm{~mm} ;{ }^{(7)}$ Total organic carbon; ${ }^{(8)}$ Sum of calcium $\left(\mathrm{Ca}^{2+}\right)$ and $\left(\mathrm{Mg}^{2+}\right)$ levels; ${ }^{(9)}$ Sum of bases; ${ }^{(10)}$ Cation exchange capacity pH 7.0; ${ }^{(1)}$ Base saturation and ${ }^{(12)}$ Aluminum saturation.

Following collection, soil samples were air-dried in a greenhouse, broken up, ground and sieved in a $4 \mathrm{~mm}$ mesh sieve, and incubated separately. Chemical analyses used soil samples sieved in a $2 \mathrm{~mm}$ mesh sieve to obtain air-dried fine earth (ADFE). $\mathrm{pH}$ in water and in $1.0 \mathrm{~mol} \mathrm{~L}^{-1} \mathrm{KCl}$ (soil-solvent ratio of 1:2.5); $\mathrm{H}+\mathrm{Al}$ by 
neutralization volumetry, after extraction with calcium acetate buffered at $\mathrm{pH} 7$ and field capacity (FC), according to (Embrapa 2011b). Chemical analyses were conducted with three repetitions and the results are presented in Table 1.

Soil incubation was performed in a greenhouse. Briefly, the treatments consisted of applying four doses of dolomite lime $(\mathrm{PRNT}=90 \%, \mathrm{CaO}=29 \%, \mathrm{MgO}=19 \%$, granulometry $=$ filler $)$, after sieving each soil in 0.25 $\mathrm{mm}$ mesh (Tedesco et al., 1995), corrected for $100 \%$ of total relative neutralizing power (TRNP), which is equivalent to that required to neutralize $0,25,50$ and $100 \%$ of $\mathrm{H}+\mathrm{Al}$ content. Each treatment had four repetitions and the doses were applied and homogenized in $20 \mathrm{~kg}$ soil samples (dry base). Next, distilled water was applied to raise $80 \%$ moisture to $\mathrm{FC}$ and the samples were then added to $100 \mathrm{~L}$ plastic bags. The plastic bags (protected by a raffia bag) were closed after adding lime and distilled water ( $80 \%$ FC) to each soil. The soil + plastic bags were weighed every 15 days to determine whether they had lost moisture. Next, they were opened for sample homogenization and oxygenation and, when necessary, to replace lost moisture. This stage was performed every 15 days, and the samples were incubated for 98 days until $\mathrm{pH}$ was stabilized.

After soil incubation and fertilization, $8 \mathrm{~L}$ pots containing $5.0 \mathrm{~kg}$ of each soil were taken to the greenhouse. Soybean was cultivated for 60 days, followed by maize in the same soil for 45 days. The experimental design consisted of random blocks, arranged in a $4 \times 5$ factorial scheme, involving four doses of lime and five soils, with four repetitions. Seven seeds were sown in each pot, without pre-germination. The plants were cut 21 and 11 days after soybean and maize emergence, respectively, leaving three plants in each pot. The soils were kept at a moisture level of $80 \%$ of $\mathrm{FC}$, via daily weighing of pots (subtracting the weight of the plants) and moisture replacement with deionized water.

Soybean plants were collected at the full flowering stage (R2) and maize with six fully developed leaves (V6). The plant shoots ( $\mathrm{SH}$ ) were cut at ground level, placed in paper bags and dried in a forced air oven at $65-70{ }^{\circ} \mathrm{C}$ until constant weight to obtain shoot dry weight (SDW). The roots of the two crops were separated from the soils using a $2 \mathrm{~mm}$ sieve. Next, they were washed in running water to remove the thickest clumps of soil, dried in a forced air oven at $65-70{ }^{\circ} \mathrm{C}$, for $24 \mathrm{~h}$ and weighed to determine root dry weight (RDW). The roots were then dried again and three from each experimental unit of each crop weighed to obtain root dry weight (RDW). Shoot (SDW) and root dry weight (RDW) were summed to obtain total dry weight (TDW) produced by the plants.

The plant tissue was ground and analyzed, as described by Miller (1998). $0.1 \mathrm{~g}$ of each sample was weighed in digestion tubes, and $5 \mathrm{~mL}$ of nitric acid and $3 \mathrm{~mL}$ of hydrogen peroxide were added, and the solution left to settle for one night (pre-digestion). All the samples were digested in a Multiwave 3000 microwave oven (Anton Paar, Graz, Austria), at a temperature of $160{ }^{\circ} \mathrm{C}$ and pressure of around 20 Bar, for 40 minutes. The product of digestion was diluted with $30 \mathrm{~mL}$ of deionized water.

$\mathrm{Ca}, \mathrm{Mg}, \mathrm{P}, \mathrm{K}$ and $\mathrm{Al}$ in these samples were quantified in an inductively coupled plasma-atomic emission spectrometer (ICP-OES) (Optima ${ }^{\circledR}$ 8300, Perkin Elmer, USA) and N concentration was determined using steam distillation in a semimicro Kjeldahl unit.

SDW, RDW, TDW and N, P, K, Ca and Mg levels were used to calculate accumulated content (Laviola \& Dias, 2008) and the following indices: absorption efficiency (AE) (Swiader et al., 1994); transport efficiency (TE) (Li et al., 1991) and use efficiency (UE) (Siddiqi et al., 1981) of each nutrient in the shoots and roots, in line with the following formulas:

$$
\begin{gathered}
N_{\text {macro and } A l}(\mathrm{mg})=T D W(\mathrm{mg}) \times \text { Nutrient concentration }(\%) / 100 \\
A E(\mathrm{mg} \text { nutrient/g RDW })=N_{A S H}(\mathrm{mg})+N_{A R}(\mathrm{mg}) / D W r o o t \\
T E(\%)=T N C_{A S H}(\mathrm{mg}) \times 100 / T N C_{A P}(\mathrm{mg}) \\
U E=\left(\mathrm{g}^{2} / \mathrm{mg} \text { of accumulated nutrient }\right)=(T D W)^{2}\left(\mathrm{~g}^{2}\right) / T N C_{A P}(\mathrm{mg})
\end{gathered}
$$

where, $N_{\text {macro and } A l}$ is the amount of macronutrients and $\mathrm{Al}$ accumulated in the plant tissue, $N_{A S H}$ nutrients accumulated in the shoots, $N_{A R}$ nutrients accumulated in the roots: $T N C_{A S H}$ total nutrient content accumulated in the shoots, $T N C_{A P}$ total nutrient content accumulated in the plants, and $T D W$ total dry weight. It is important to underscore that these indices were calculated from the data presented in Table 2.

After the roots were separated from each crop, the soils were homogenized and samples weighing approximately $140 \mathrm{~g}$ were collected and packed in Styrofoam containers containing ice. Next, they were stored in an ultrafreezer at $-80{ }^{\circ} \mathrm{C}$, where they remained until analysis. Subsequently, the same procedures were performed to obtain the ADFE reported previously. 
The following chemical attributes were determined in the ADFE: $\mathrm{pH}$ in water, $\mathrm{pH}$ in $0.01 \mathrm{~mol} \mathrm{~L}^{-1} \mathrm{CaCl}_{2}(1: 2.5$ soil-solution ratio) and $\mathrm{pH}$ in $1 \mathrm{~mol} \mathrm{~L}^{-1} \mathrm{KCl}(1: 10$ soil-solution ratio) and, according to Tedesco et al. (1995), exchangeable soil $\mathrm{Ca}^{2+}, \mathrm{Mg}^{2+}, \mathrm{K}^{+}$and $\mathrm{Al}^{3+}$ levels. $\mathrm{P}, \mathrm{K}^{+}$and $\mathrm{Na}^{+}$were extracted using the Melich-1 solution, the first determined by colorimetry (Murphy \& Riley, 1962) and the last two by flame photometry.

The soil solution was extracted by weighing $20 \mathrm{~g}$ of ADFE in $50 \mathrm{~mL}$ polyethylene (Falcon) tubes and then 20 $\mathrm{mL}$ of ultrapure water. The samples were agitated in a horizontal device for 15 minutes at $150 \mathrm{rpm}$, and allowed to rest for 1 hour. Next, they were agitated for five more minutes and centrifuged at $2000 \mathrm{rpm}$ for 30 minutes. $\mathrm{pH}$ and electrical conductivity (EC) were measured and $\mathrm{Ca}^{2+}, \mathrm{Mg}^{2+}, \mathrm{K}^{+}, \mathrm{Al}^{3+}, \mathrm{SO}_{4}^{2-}, \mathrm{Cl}^{-}, \mathrm{NO}_{3}{ }^{-}, \mathrm{PO}_{4}{ }^{3-}$ and DOC determined. Chemical spetiation of the soil solution was estimated using the Visual Minteq program, version 3.1, based on the Minteq A2 program, version 4.0 (Gustafsson, 2016). Further details can be checked in Cunha et al. (2018a, 2018b).

Table 2. Root (RDW) and total dry weight (TDW) and macronutrient and aluminum content in the shoots and roots of maize plants grown in acidic soils

\begin{tabular}{|c|c|c|c|c|c|c|c|c|c|c|c|c|c|c|c|}
\hline \multirow{3}{*}{ Soil $^{(1)}$} & \multirow{3}{*}{ Lime doses $^{(2)}$} & \multirow{3}{*}{ RDW } & \multirow{3}{*}{ TDW } & \multicolumn{12}{|c|}{ Nutrient Content } \\
\hline & & & & \multicolumn{6}{|c|}{ Shoot } & \multicolumn{6}{|c|}{ Root } \\
\hline & & & & $\overline{\mathrm{Ca}}$ & Mg & $\mathbf{N}$ & $\mathbf{P}$ & $\mathbf{K}$ & Al & $\overline{\mathrm{Ca}}$ & $\mathrm{Mg}$ & $\mathbf{N}$ & $\mathbf{P}$ & $\mathbf{K}$ & Al \\
\hline & $\mathrm{t} \mathrm{ha}^{-1} \times \mathrm{H}+\mathrm{Al}$ & $\begin{array}{l}------ \\
--\end{array}$ & S------- & - & - & 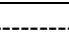 & $\ldots$ & ---י & ------ & ----- & ---- & ---- & - & ----- & - \\
\hline \multirow{4}{*}{ AC9 } & 0 & 4.76 & 18.04 & 0.55 & 0.47 & 6.68 & 0.40 & 13.7 & 0.04 & 0.19 & 0.11 & 1.82 & 0.55 & 1.05 & 0.56 \\
\hline & 0.25 & 3.75 & 13.97 & 0.47 & 0.52 & 8.34 & 0.40 & 15.5 & 0.04 & 0.21 & 0.13 & 1.84 & 0.42 & 0.89 & 0.56 \\
\hline & 0.5 & 4.09 & 15.63 & 0.50 & 0.62 & 8.40 & 0.41 & 20.1 & 0.05 & 0.22 & 0.12 & 1.80 & 0.39 & 1.11 & 0.41 \\
\hline & 1.00 & 5.42 & 18.15 & 0.60 & 0.86 & 8.79 & 0.37 & 22.3 & 0.05 & 0.34 & 0.17 & 1.73 & 0.45 & 1.52 & 0.37 \\
\hline \multirow{4}{*}{ PE } & 0 & 0.56 & 1.59 & 0.29 & 0.38 & 3.79 & 0.28 & 2.76 & 0.07 & 0.19 & 0.18 & 2.02 & 0.40 & 0.00 & 0.71 \\
\hline & 0.25 & 1.66 & 4.03 & 0.28 & 0.40 & 3.81 & 0.23 & 3.16 & 0.05 & 0.18 & 0.14 & 3.19 & 0.49 & 0.52 & 0.43 \\
\hline & 0.5 & 2.67 & 7.13 & 0.34 & 0.93 & 7.45 & 0.24 & 8.68 & 0.74 & 0.20 & 0.15 & 1.96 & 0.73 & 1.01 & 0.45 \\
\hline & 1.00 & 3.29 & 8.65 & 0.50 & 0.95 & 7.69 & 0.26 & 11.50 & 0.07 & 0.27 & 0.21 & 2.24 & 0.42 & 1.35 & 0.40 \\
\hline \multirow{4}{*}{$\mathrm{RS}$} & 0 & 4.60 & 16.61 & 0.42 & 0.63 & 7.32 & 0.37 & 10.17 & 0.05 & 0.19 & 0.12 & 1.68 & 0.48 & 1.18 & 0.36 \\
\hline & 0.25 & 5.14 & 20.52 & 0.50 & 0.68 & 8.01 & 0.39 & 10.84 & 0.09 & 0.20 & 0.14 & 1.63 & 0.39 & 1.44 & 0.28 \\
\hline & 0.5 & 4.96 & 21.84 & 0.50 & 0.79 & 7.36 & 0.31 & 12.03 & 0.03 & 0.22 & 0.15 & 1.68 & 0.40 & 1.46 & 0.35 \\
\hline & 1.00 & 5.24 & 17.75 & 0.78 & 1.06 & 7.44 & 0.33 & 13.41 & 0.04 & 0.39 & 0.28 & 1.84 & 0.47 & 1.33 & 0.46 \\
\hline \multirow{4}{*}{ BR } & 0 & 0.30 & 0.94 & 0.21 & 0.08 & 4.03 & 0.26 & 2.37 & 0.03 & 0.11 & 0.03 & 2.53 & 0.00 & 0.22 & 0.20 \\
\hline & 0.25 & 3.28 & 10.94 & 0.35 & 0.56 & 8.21 & 0.32 & 11.73 & 0.08 & 0.20 & 0.11 & 1.58 & 0.53 & 0.71 & 0.18 \\
\hline & 0.5 & 3.97 & 14.32 & 0.54 & 0.97 & 8.74 & 0.34 & 12.46 & 0.06 & 0.22 & 0.13 & 1.61 & 0.59 & 1.15 & 0.20 \\
\hline & 1.00 & 4.76 & 15.51 & 0.86 & 1.26 & 7.34 & 0.29 & 11.83 & 0.06 & 0.31 & 0.22 & 1.55 & 0.45 & 0.86 & 0.19 \\
\hline \multirow{4}{*}{ CB } & 0 & 1.83 & 5.13 & 0.25 & 0.45 & 3.51 & 0.32 & 3.08 & 0.02 & 0.18 & 0.04 & 1.61 & 0.41 & 0.21 & 0.49 \\
\hline & 0.25 & 4.34 & 11.89 & 0.51 & 0.58 & 7.33 & 0.38 & 12.78 & 0.10 & 0.19 & 0.07 & 1.94 & 0.34 & 0.75 & 0.39 \\
\hline & 0.5 & 4.79 & 14.03 & 0.47 & 0.80 & 6.82 & 0.32 & 14.07 & 0.05 & 0.24 & 0.11 & 1.73 & 0.45 & 1.19 & 0.44 \\
\hline & 1.00 & 4.02 & 10.17 & 0.59 & 0.96 & 5.47 & 0.26 & 14.49 & 0.07 & 0.39 & 0.22 & 1.78 & 0.41 & 1.22 & 0.42 \\
\hline
\end{tabular}

Note. ${ }^{(1)}$ AC9: collected in Tarauacá, Acre state; Profile 9; PE: collected in Ipojuca, Pernambuco state; RS: collected in Rosário do Sul, Rio Grande do Sul state; BR: collected in Bom Retiro, Santa Catarina (SC) state; CB: collected in Curitibanos, $\mathrm{SC} ;{ }^{(2)}$ Lime doses applied to the soils.

\subsection{Soybean and Maize Plant Properties}

Soybean (BRS 232): $88 \%$ seed germination, semi-premature, moderately sensitive to the presence of aluminum in the soil, determinate growth and high yield potential, indicated for South and Southeastern Brazil.

Maize (30F53YHR hybrid): $100 \%$ seed germination, premature, moderately sensitive to the presence of aluminum in the soil, high yield potential, highly adaptable and good response to crop management, recommended for several Brazilian regions. 


\subsection{Statistical Analysis}

Data related to TDW, efficiencies (AE, TE and UE) and nutrient accumulation in maize plants with lime doses applied to soils were submitted to analysis of variance (F-test) using SISVAR 5.6 software (Ferreira, 2014). When there was a significant effect, Tukey's test was applied to the "soil types" factor. The regression test was applied to the "lime doses" factor, both at 5\% error probability. For each evaluated factor was included the unfolding of limestone doses in each of the soil types.

It is important to underscore that due to the similar results for soil chemical analysis and curve behavior in terms of absorption efficiency, transport, use and accumulation after the soybean and maize cultivation, only results of the second crop will be presented.

\section{Results and Discussion}

\subsection{Soil Chemical Properties}

As expected, liming increased soil $\mathrm{pH}, \mathrm{Ca}^{2+}, \mathrm{Mg}^{2+}, \mathrm{S}$ and $\mathrm{V} \%$ levels and reduced $\mathrm{Al}^{3+}$ and $\mathrm{H}+\mathrm{Al}$ and $\mathrm{Al}^{3+}$ saturation in all the soils (Table 3). However, $\mathrm{Al}^{3+}$ was not completely neutralized in AC9 and PE soil samples with the dose used $\left(100 \%\right.$ of $\mathrm{H}+\mathrm{Al}$ content). The incomplete $\mathrm{Al}^{3+}$ neutralization in these two soils may have occurred due to underestimation of potential acidity by calcium acetate, since other Al fractions may not have been computed in $\mathrm{H}+\mathrm{Al}$, resulting in incorrect estimation of lime requirements (Kaminski et al., 2002; Júnior et al., 2015). It could also be related to the lime not neutralizing other forms of Al, which may have been extracted by the $\mathrm{KCl}$ solution and computed as exchangeable after base titration. 
Table 3. Soil chemical properties after lime application in samples collected after maize cultivation in a greenhouse

\begin{tabular}{|c|c|c|c|c|c|c|c|c|c|}
\hline \multirow{2}{*}{ Soil $^{(1)}$} & \multirow{2}{*}{ Limestone dose $^{(2)}$} & \multicolumn{3}{|c|}{ pH } & \multirow{2}{*}{$\Delta \mathbf{p} \mathbf{H}^{(3)}$} & \multirow{2}{*}{$\mathbf{A l}^{3+}$} & \multirow{2}{*}{$\mathbf{H}+\mathbf{A l}$} & \multirow{2}{*}{$\mathrm{Ca}^{2+}$} & \multirow{2}{*}{$\mathbf{M g}^{2+}$} \\
\hline & & Water & $\mathrm{CaCl}_{2}$ & KCl & & & & & \\
\hline & $\mathrm{tha}^{-1} \times \mathrm{H}+\mathrm{Al}$ & & $0.01 \mathrm{~mol} \mathrm{~L}^{-1}$ & $1 \mathrm{~mol} \mathrm{~L}^{-1}$ & & ----------- & $-----c$ & 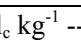 & ----------- \\
\hline & & ------- & 2.5 ---------- & $1: 10$ & & & & & \\
\hline \multirow{4}{*}{ AC9 } & 0 & 4.85 & 4.58 & 3.72 & -1.13 & 13.2 & 14.9 & 17.5 & 3.6 \\
\hline & 0.25 & 5.45 & 5.38 & 3.89 & -1.56 & 9.3 & 10.7 & 18.8 & 5.2 \\
\hline & 0.5 & 5.58 & 5.52 & 3.99 & -1.59 & 5.6 & 9.2 & 22.9 & 6.5 \\
\hline & 1.00 & 5.84 & 5.75 & 4.10 & -1.74 & 3.1 & 6.7 & 24.9 & 6.8 \\
\hline \multirow{4}{*}{ PE } & 0 & 4.66 & 4.59 & 3.90 & -0.76 & 18.1 & 18.5 & 2.9 & 2.0 \\
\hline & 0.25 & 4.97 & 4.89 & 4.03 & -0.94 & 13.7 & 15.8 & 6.9 & 3.7 \\
\hline & 0.5 & 5.59 & 5.52 & 4.15 & -1.44 & 8.9 & 10.8 & 7.1 & 5.6 \\
\hline & 1.00 & 5.90 & 5.82 & 4.41 & -1.49 & 1.4 & 9.0 & 14.3 & 6.3 \\
\hline \multirow{4}{*}{ RS } & 0 & 5.01 & 4.94 & 3.80 & -1.21 & 6.9 & 9.0 & 8.8 & 2.9 \\
\hline & 0.25 & 5.73 & 5.66 & 3.90 & -1.83 & 4.6 & 7.9 & 9.7 & 3.8 \\
\hline & 0.5 & 5.82 & 5.75 & 4.02 & -1.8 & 2.7 & 6.6 & 10.1 & 4.0 \\
\hline & 1.00 & 6.18 & 6.11 & 4.47 & -1.71 & 0.4 & 3.9 & 14.8 & 5.7 \\
\hline \multirow{4}{*}{ BR } & 0 & 4.82 & 4.75 & 3.86 & -0.96 & 5.4 & 9.0 & 0.38 & 0.0 \\
\hline & 0.25 & 5.56 & 5.49 & 3.89 & -1.67 & 3.7 & 7.9 & 4.6 & 1.4 \\
\hline & 0.5 & 5.83 & 5.74 & 4.08 & -1.75 & 1.5 & 6.0 & 5.5 & 2.0 \\
\hline & 1.00 & 6.09 & 6.02 & 4.45 & -1.64 & 0.2 & 4.3 & 7.3 & 3.5 \\
\hline \multirow{6}{*}{$\mathrm{CB}$} & 0 & 4.74 & 4.69 & 4.10 & -0.64 & 2.0 & 8.0 & 0.16 & 0.0 \\
\hline & 0.25 & 5.63 & 5.56 & 4.28 & -1.35 & 0.8 & 6.7 & 3.7 & 0.7 \\
\hline & 0.5 & 5.81 & 5.74 & 4.54 & -1.27 & 0.3 & 5.7 & 4.7 & 1.4 \\
\hline & 1.00 & 6.19 & 6.10 & 5.22 & -0.97 & 0.0 & 4.3 & 6.2 & 2.5 \\
\hline & & $\mathrm{Na}^{+}$ & $\mathbf{K}^{+}$ & $\mathbf{S}^{(4)}$ & $\mathrm{CECpH}^{(5)}$ & CECe $^{(6)}$ & $V^{(7)}$ & $\mathbf{m}^{(8)}$ & $\mathbf{P}$ \\
\hline & & ------ & ----------------- & $\mathrm{cmol}_{\mathrm{c}} \mathrm{kg}^{-1}$ & ---------------- & ------------ & ------ & 0 ------ & $\mathrm{mg} \mathrm{kg}^{-1}$ \\
\hline \multirow{4}{*}{ AC9 } & 0 & 0.00 & 0.48 & 21.6 & 36.5 & 34.8 & 59 & 38 & 16.3 \\
\hline & 0.25 & 0.00 & 0.65 & 24.7 & 35.4 & 33.9 & 70 & 27 & 16.2 \\
\hline & 0.5 & 0.00 & 0.69 & 30.1 & 39.3 & 35.7 & 77 & 16 & 14.4 \\
\hline & 1.00 & 0.00 & 0.73 & 32.4 & 39.1 & 35.5 & 83 & 9 & 14.9 \\
\hline \multirow{4}{*}{ PE } & 0 & 0.00 & 0.68 & 5.6 & 24.1 & 23.7 & 23 & 76 & 17.3 \\
\hline & 0.25 & 0.00 & 0.53 & 11.1 & 26.9 & 24.9 & 41 & 55 & 18.1 \\
\hline & 0.5 & 0.00 & 0.44 & 13.1 & 24.0 & 22.1 & 55 & 40 & 16.6 \\
\hline & 1.00 & 0.00 & 0.43 & 21.0 & 30.1 & 22.5 & 70 & 6 & 15.6 \\
\hline \multirow{4}{*}{ RS } & 0 & 0.00 & 0.40 & 12.1 & 21.1 & 19.0 & 57 & 36 & 17.8 \\
\hline & 0.25 & 0.00 & 0.39 & 13.9 & 21.8 & 18.6 & 64 & 25 & 15.4 \\
\hline & 0.5 & 0.00 & 0.34 & 14.4 & 21.0 & 17.1 & 69 & 16 & 15.7 \\
\hline & 1.00 & 0.00 & 0.34 & 20.8 & 24.7 & 21.2 & 84 & 2 & 15.3 \\
\hline \multirow{4}{*}{ BR } & 0 & 0.00 & 0.51 & 0.9 & 9.9 & 6.4 & 9 & 85 & 14.0 \\
\hline & 0.25 & 0.00 & 0.31 & 6.3 & 14.2 & 10.1 & 44 & 37 & 13.7 \\
\hline & 0.5 & 0.00 & 0.41 & 7.9 & 13.9 & 9.4 & 57 & 16 & 13.0 \\
\hline & 1.00 & 0.00 & 0.29 & 11.1 & 15.3 & 11.4 & 72 & 2 & 12.2 \\
\hline \multirow{4}{*}{ CB } & 0 & 0.00 & 0.48 & 0.6 & 8.6 & 2.7 & 7 & 74 & 4.3 \\
\hline & 0.25 & 0.00 & 0.34 & 4.7 & 11.5 & 5.6 & 41 & 14 & 3.3 \\
\hline & 0.5 & 0.00 & 0.43 & 6.5 & 12.2 & 6.8 & 54 & 4 & 3.1 \\
\hline & 1.00 & 0.00 & 0.40 & 9.1 & 13.4 & 9.1 & 68 & 0 & 3.2 \\
\hline
\end{tabular}

Note. ${ }^{(1)}$ AC9: collected in Tarauacá, Acre state; Profile 9; PE: collected in Ipojuca, Pernambuco state; RS: collected in Rosário do Sul, Rio Grande do Sul state; BR: collected in Bom Retiro, Santa Catarina (SC) state; CB: collected in Curitibanos, SC; ${ }^{(2)}$ Lime doses applied to the soils; ${ }^{(3)}$ Delta $\mathrm{pH}$ (pH KCl-pH water); ${ }^{(4)}$ Sum of the bases; ${ }^{(5)}$ Cation exchange capacity $\mathrm{pH} 7 ;{ }^{(6)}$ Effective cation exchange capacity; ${ }^{(7)}$ Base saturation; ${ }^{(8)}$ Aluminum saturation.

The liming decreased the $\mathrm{Al}$ content in the RS, BR and $\mathrm{CB}$ soils, but did not promote its complete neutralization. The values were still high in the soils AC9 $\left(3.1 \mathrm{cmol}_{\mathrm{c}} \mathrm{kg}^{-1}\right)$ and PE $\left(1.4 \mathrm{cmol}_{\mathrm{c}} \mathrm{kg}^{-1}\right)$ even at the highest dose. Al saturation decreased in all soils with increasing limestone doses (Table 3). In an earlier study, using the same soils as the present investigation, Cunha et al. $(2014,2015)$ suggest that part of the $\mathrm{Al}-\mathrm{KCl}$ does not represent the 
exchangeable forms of $\mathrm{Al}$, since the high concentration of $\mathrm{KCl}\left(1.0 \mathrm{~mol} \mathrm{~L}^{-1}\right)$ may hydrolyze some of the non-exchangeable forms of $\mathrm{Al}$, possibly originating in the amorphous compounds of these soils, overestimating its exchangeable content and, in turn, $\mathrm{Al}$ saturation (Table 3). Overestimating $\mathrm{Al}-\mathrm{KCl}$ may mask $\mathrm{Al}$ toxicity to plants, since the amount of $\mathrm{Al}$ extracted and quantified may be greater than the actual aluminum toxicity in roots (Ebeling et al., 2008; Bernini et al., 2013; Cunha et al., 2018a, 2018b). The P levels in AC9, PE, RS and BR soils after cultivation were very high (Table 3 ), which may partially decrease plant response to lime application (Ernani et al., 2000).

All the soils exhibited a net negative charge, indicated by the $\Delta \mathrm{pH}$ values. The $\mathrm{pH}$ values in $0.01 \mathrm{~mol} \mathrm{~L}^{-1} \mathrm{CaCl}_{2}$ and $1 \mathrm{~mol} \mathrm{~L}^{-1} \mathrm{KCl}$ were always lower than those obtained by $\mathrm{pH}$ in water, even with the increase in lime doses. There were no changes in $\mathrm{K}^{+}$and $\mathrm{Na}^{+}$content with the application of lime doses or significant alterations in CEC at $\mathrm{pH}$ 7, which was expected because the increase in $\mathrm{Ca}^{2+}$ and $\mathrm{Mg}^{2+}$ should be stoichiometrically similar to the decline in $\mathrm{H}+\mathrm{Al}$. The $\mathrm{P}$ levels in AC9, PE, RS and BR soils in samples collected after the maize harvest were very high. An exception occurred in CB soil, in which the exchangeable levels of this element were low (Table $3)$.

Although exchangeable $\mathrm{Al}(\mathrm{Al}-\mathrm{KCl})$ in AC9 and RS soils was high, base saturation was above $50 \% . \mathrm{Al}$ saturation in these soils was greater than $30 \%$ (Table 3), which would normally be toxic to plants (Smyth and Cravo, 1992; Hashimoto et al., 2010), but fell below 30\% after the first lime dose, suggesting that plants may no longer exhibit Al toxicity (Wadt, 2002). In the other soils (PE, BR and CB) liming increased base saturation, reaching values above $50 \%$ with the second dose $(50 \%$ of $\mathrm{H}+\mathrm{Al})$, and $\mathrm{Al}$ saturation declined to less than $30 \%$, except in PE soil (Table 3). This seems to indicate that after this dose, even high levels of Al-KCl may no longer have a toxic effect.

\subsection{Efficiency in Nutrient and Al Absorption, Transport, Use and Accumulation in Plants}

The order of absorption (Figure 1), transport (data not shown), use (Figure 2) and subsequent accumulation (Figure 3) of N, P, K, Ca, Mg changed according to their availability and increased levels in the soil solution with the application of lime and, primarily, plants' need of these nutrients to produce SDW, RDW and TDW (Table 2).

The macronutrient content in leaves, stems and roots obtained from maize plants cultivated in AC9, PE, RS, BR and CB soils was also influenced by liming and always remained at normal levels for these crops, according to Tedesco et al. (1995) and Silva et al. (2009).

Similar behavior occurred with Al, but, as expected, the highest concentrations of this element were found in the roots compared to the shoots. However, applying lime doses reduced levels of this element in the shoots and particularly the roots (Table 2).

The AE, TE, UE indices and nutrient accumulation in maize plant tissues ( $\left.\mathrm{NA}_{\mathrm{MP}}\right)$ exhibited quadratic adjustment and high correlation with lime doses in most soils, regardless of the doses applied. In general, the following decreasing order was found for the indices (efficiencies): $\mathrm{AE}: \mathrm{K}>\mathrm{N}>\mathrm{Ca}>\mathrm{Mg}>\mathrm{P}>\mathrm{Al}$; $\mathrm{TE}: \mathrm{K}>\mathrm{N}>\mathrm{Mg}>\mathrm{Ca}>$ $\mathrm{P}>\mathrm{Al}$ and UE: $\mathrm{Mg}>\mathrm{Al}>\mathrm{P}>\mathrm{Ca}>\mathrm{N}>\mathrm{K}$ and for accumulated nutrients: $\mathrm{K}>\mathrm{N}>\mathrm{P}>\mathrm{Ca}>\mathrm{Mg}<\mathrm{Al}$.

$\mathrm{K}$ was the nutrient most absorbed (Figure 1), transported (data not shown) and accumulated (Figure 2) by maize plants, followed by N, but both were influenced by liming, as observed by Castro et al. (2015). Liming increased plant $\mathrm{N}$ and $\mathrm{K}$ absorption and accumulation in all the soils, and was more pronounced in the second dose, similar to that of the first and declining with the maximum dose used. Concomitantly, the first two doses showed a decline in transport and use of these nutrients for DW production. This decrease may have occurred due to the accumulation of these nutrients in maize plant tissues ( $\mathrm{NA}_{\mathrm{MP}}$ ) (Figure 2), which was higher in $\mathrm{CB}$ soil (Figure 2e). This interpretation is supported by Riedell (2010), Zoca et al. (2014), and Liu et al. (2017).

The decline of these nutrients $(\mathrm{N}$ and $\mathrm{K})$ in the plant tissues assessed may also be related to increased availability of $\mathrm{Ca}^{2+}$ and $\mathrm{Mg}^{2+}$ in all the soils with a rise in lime doses (Salvador et al., 2011; Ertiftik \& Zenging, 2017). With liming, both absorption (Figure 1) and transport (data not shown) of $\mathrm{Ca}$ and, to a lesser extent, $\mathrm{Mg}$, increased, in addition to raising $\mathrm{NA}_{\mathrm{MP}}$ cultivated in $\mathrm{PE}, \mathrm{RS}, \mathrm{BR}$ and $\mathrm{CB}$ soils (Figure 3). The greater accumulation of $\mathrm{Ca}$ in plants is related to the non-redistribution of this nutrient after absorption by the roots and translocation to the shoots, due to its low mobility (Hepler, 2005; Horst et al., 2010; Lima et al., 2011). The lower accumulation of Mg may be related to its greater use (Figure 3) for TDW conversion in these plants (Gransee \& Fürs, 2012). Moreover, it is plausible that this decline may have occurred due to the dilution of these nutrients in the plant tissues, as observed by Riedell (2010), Junio et al. (2013) and Martins et al. (2017). However, in the case of AC9, liming had no influence on the K supply to plants, as reported by Caires and Fonseca (2000). 
(a)

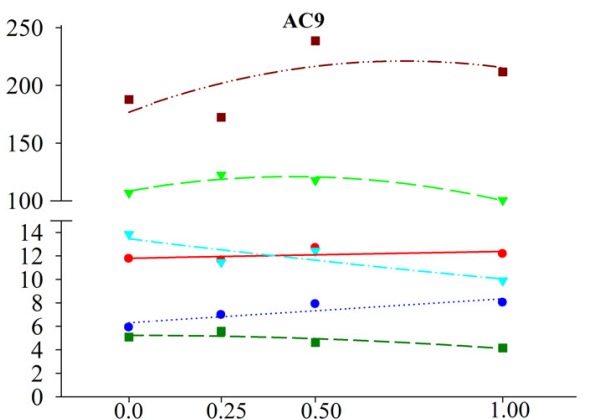

- $\mathrm{AEF}_{\mathrm{CaP}}=11.80+0.58 \mathrm{x} \mathrm{r}^{2}=0.27$

- $\quad \mathrm{AEFMgP}_{\mathrm{Mg}}=6.30+2.04 \mathrm{x}^{2}=0.79$

v $\quad \mathrm{AEF}_{N P}=108.35+57.37 \mathrm{x}-65.32 \mathrm{x}^{2} \mathrm{r}^{2}=0.91$

- AEFPP $=13.46-3.88 \mathrm{x}+0.45 \mathrm{x}^{2} \mathrm{r}^{2}=0.77$

- $A E F K P=176.72+120.56 x-81.95 x^{2} r^{2}=0.41$

- $\quad$ AEFAlP $=5.24-0.05 x-1.09 x^{2} r^{2}=0.73$

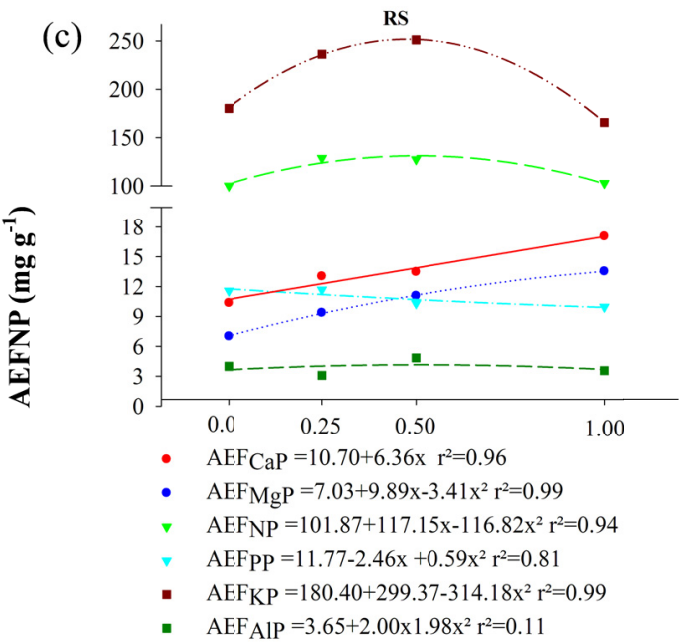

(b)

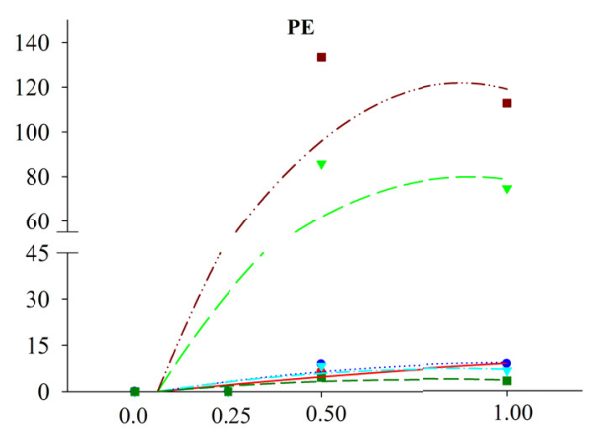

- $\mathrm{AEFCaP}_{\mathrm{C}}=-0.81+12.94 \mathrm{x}-2.90 \mathrm{x}^{2} \mathrm{r}^{2}=0.86$

- $\mathrm{AEF}_{\mathrm{MgP}}=-1.21+20.21 \mathrm{x}-9.85 \mathrm{x}^{2} \mathrm{r}^{2}=0.73$

- $\mathrm{AEF}_{\mathrm{NP}}=-12+204.01 \mathrm{x}-113.17 \mathrm{x}^{2} \mathrm{r}^{2}=0.73$

AEFPP $=-1.18+20.31 x-12.21 x^{1} r^{2}=0.70$

- $\quad \mathrm{AEF}_{K P}=-18.76+320.88 \mathrm{x}-183.14 \mathrm{x}^{2} \mathrm{r}^{2}=0.72$

- AEF $_{\mathrm{AlP}}=-0.67+11.73 \mathrm{x}-7.63 \mathrm{x}^{2} \mathrm{r}^{2}=0.66$

(d)

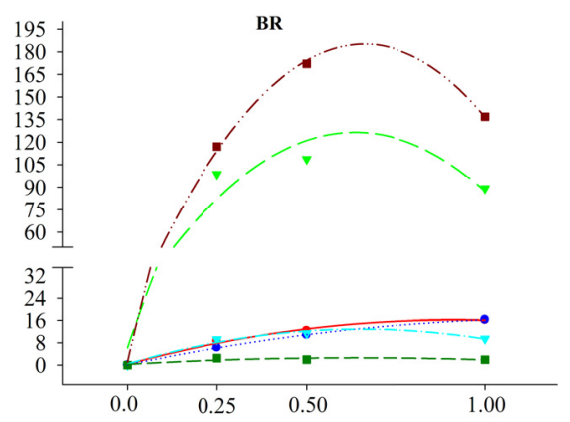

- $\quad \mathrm{AEF}_{\mathrm{CaP}}=0.30+84.88 \mathrm{x}-19.14 \mathrm{x}^{2} \mathrm{r}^{2}=0.99$

- $\quad \mathrm{AEF}_{\mathrm{MgP}}=0.04+27.19 \mathrm{x}-11.03 \mathrm{x}^{2} \mathrm{r}^{2}=0.99$

v $A E F N P=6.16+379.14 x+298.73 x^{2} r^{2}=0.94$

v $A E F P P=0.41+38.31 x-29.39 x^{2} r^{2}=0.97$

- $\mathrm{AEF}_{\mathrm{KP}}=1.10+557.26 \mathrm{x}-421.70 \mathrm{x}^{2} \mathrm{r}^{2}=0.99$

- $\quad$ AEF $_{\text {AIP }}=0.27+7.35 x-5.76 \mathrm{x}^{2} \mathrm{r}^{2}=0.75$

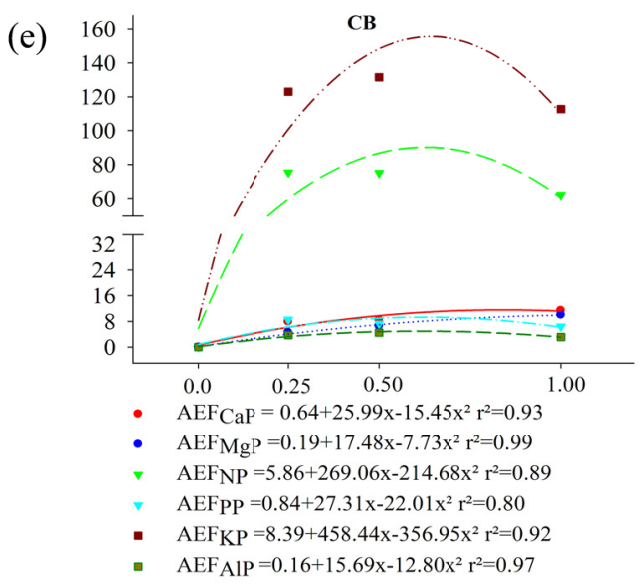

Lime Doses $\times$ H+Al (t ha-1)

Figure 1. Relation between the nutrient absorption efficiency of maize plants (AEFNP) with soil lime doses from a) Acre (AC9); b) Pernambuco (PE); c) Rosário do Sul (RS); d) Bom Retiro (BR) and Curitibanos (CB) 
(a)

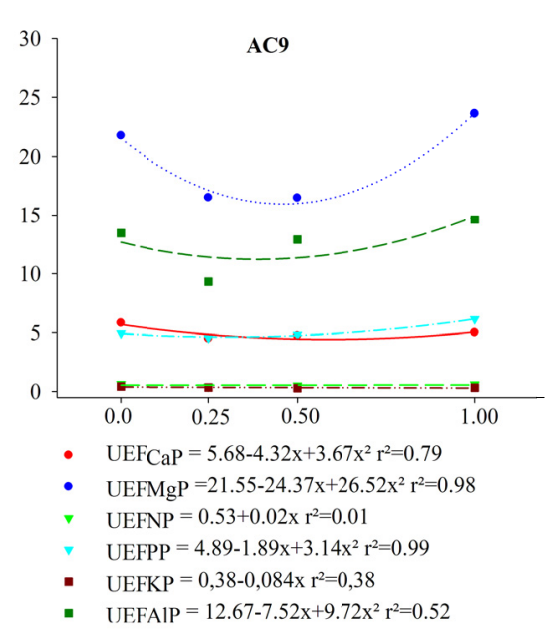


RS

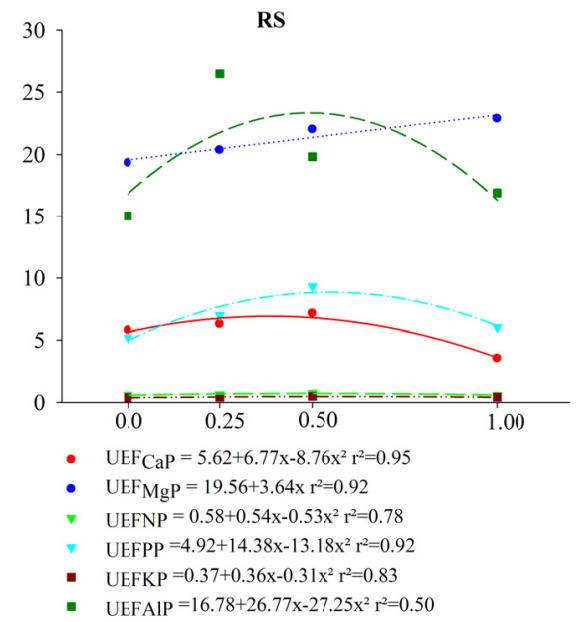

(b)

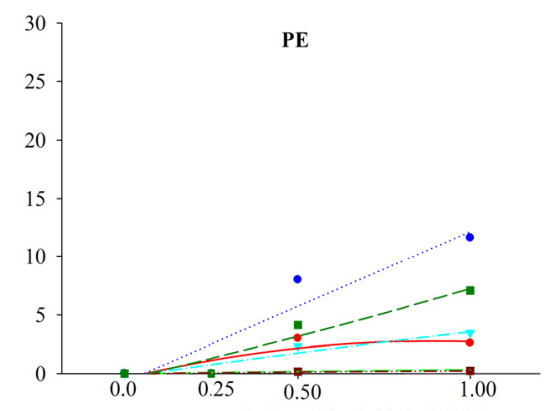

- UEFCaAP $=-0.42+7.09 x-3.92 x^{2} r^{2}=0.73$

- UEFMgP $-0.94+12.73 \mathrm{x} \mathrm{r}^{2-0.88}$

- UEFNP $=0,03+0,43 \mathrm{x}-0,09 \mathrm{x}^{2} \mathrm{r}^{2}=0,87$

v UEFPP $=-0.28+4.23 \mathrm{x}-0.37 \mathrm{x}^{2} \mathrm{r}^{2}=0.89$

- UEFKP $=0.02+0.32 \mathrm{x}-0.07 \mathrm{x}^{2} \mathrm{r}^{3}=0.87$

- UEFAIP $=-0.60+7.78 \times \mathrm{x} \mathrm{r}^{2}=0.92$

(d)

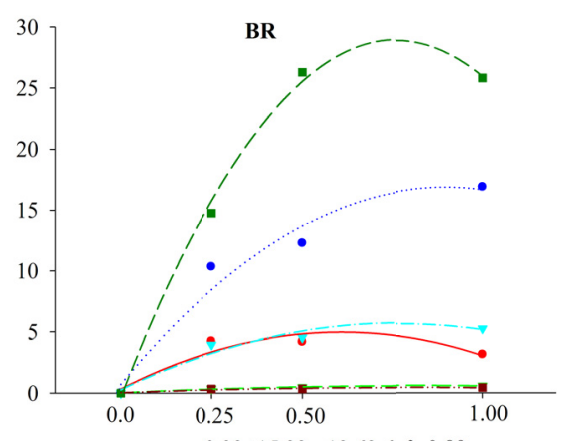

- UEFCaP $-0.32+15.32 x-12.62 x^{2} r^{2}=0.89$

- UEFMgP $=0.71+35.95 \mathrm{x}-20.02 \mathrm{x}^{2} \mathrm{r}^{2}=0.95$

V UEFNP $=0.02+1.43 x-0.88 x^{2} r^{2}=0.98$

VEFPP $=0.26+14.21 \mathrm{x}-9.22 \mathrm{x}^{2} \mathrm{r}^{2}=0.95$

- UEFKP $=0.02+1.10 \mathrm{x}-0.71 \mathrm{x}^{2} \mathrm{r}^{2}=0.92$

- UEFAlP $=-0.38+77.26 x-50.88 x^{1} r^{2}=0.99$

(e)

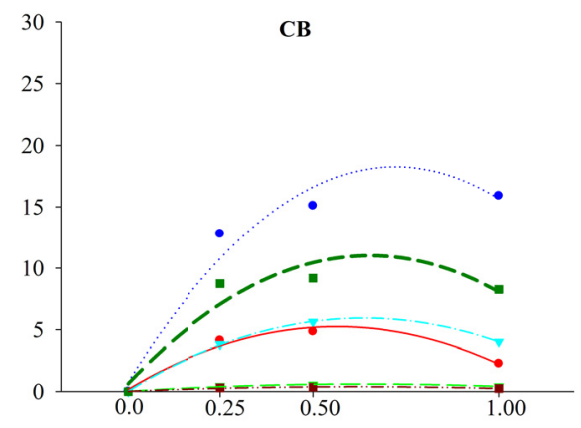

- IJEFCaP $=0.17+18.06 \mathrm{x}-16.00 \mathrm{x}^{2} \mathrm{r}^{2}=0.98$

- $\operatorname{UEFMgP}=0.76+48.54 \mathrm{x}-33.64 \mathrm{x}^{2} \mathrm{r}^{2}=0.96$

$\checkmark \quad$ UEFNP $=0.02+1.87 \mathrm{x}-1.47 \mathrm{x}^{2} \mathrm{r}^{2}=0.98$

v UEFPP $=0.02+18.62 \mathrm{x}-14.64 \mathrm{x}^{2} \mathrm{r}^{2}=0.99$

- UEFKP $=0.014+1.22 \mathrm{x}-0.09 \mathrm{x}^{2} \mathrm{r}^{2}=0.96$

- UEFAIP $=0.63+31.83 \mathrm{x}-24.41 \mathrm{x}^{2} \mathrm{r}^{2}=0.92$

Lime Doses $\times \mathrm{H}+\mathrm{Al}\left(\mathrm{t} \mathrm{ha}^{-1}\right)$

Figure 2. Relation between efficiency of nutrient use by maize plants (UEFNP) with soil lime doses from a) Acre (AC9); b) Pernambuco (PE); c) Rosário do Sul (RS); d) Bom Retiro (BR) and Curitibanos (CB) 
(a)
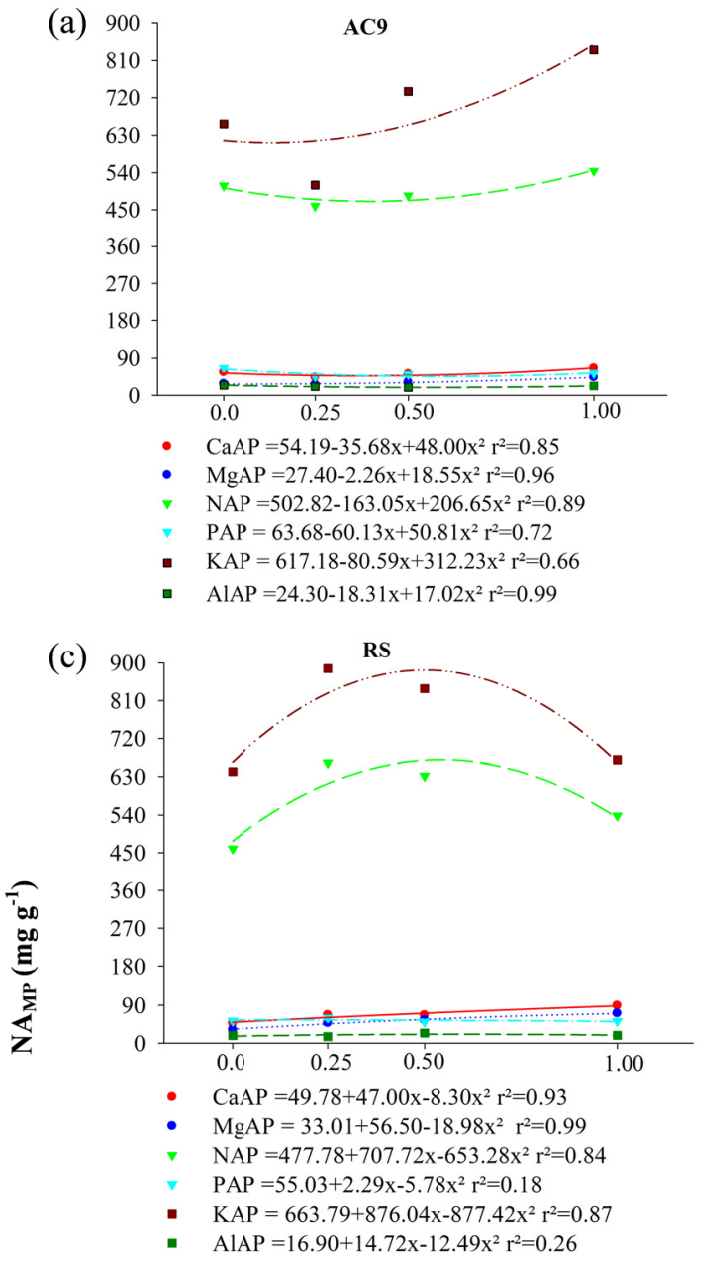

(e)

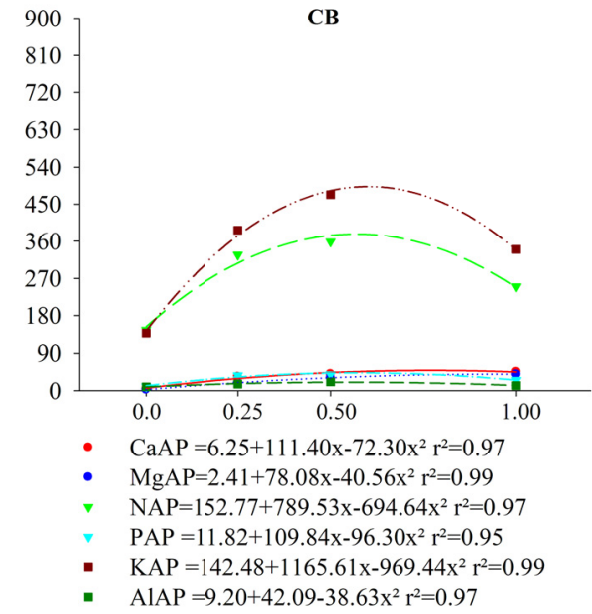

(b)

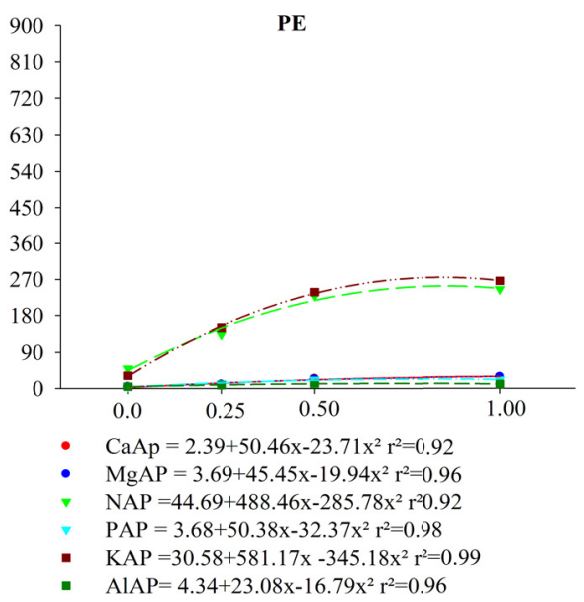

(d)

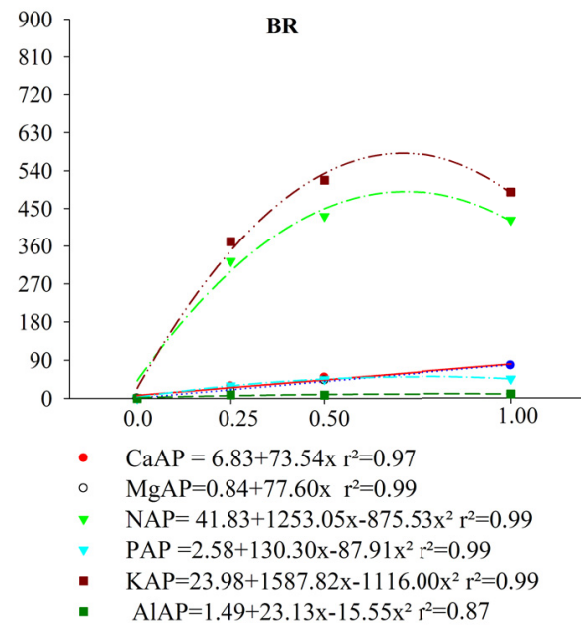

Lime Doses $\times \mathbf{H}+\mathbf{A l}\left(\mathbf{t ~ h a}^{-1}\right)$

Figure 3. Relation between nutrient accumulation in maize plant tissues $\left(\mathrm{NAT}_{\mathrm{MP}}\right)$ with soil lime doses from a) Acre (AC9); b) Pernambuco (PE); c) Rosário do Sul (RS); d) Bom Retiro (BR) and Curitibanos (CB)

In general, the order of absorption (Figure 1), transport (data not shown), use (Figure 3) and subsequent accumulation (Figure 2) of $\mathrm{Ca}$ and $\mathrm{Mg}$ changes according to their increased availability in the soil (Table 3) with liming (Joris et al., 2013), primarily with plants' need for these nutrients in SDW, RDW and TDW production (Table 2). With a rise in lime doses, regardless of the soil in which the plants were grown, the levels of these absorbed (Figure 1), transported (data not shown), and accumulated nutrients also increased (Figure 3). The greater accumulation of $\mathrm{Ca}$ is related to the non-redistribution of this nutrient inside the plant after absorption by 
the roots and translocation to the shoots, because of its low mobility (Horst et al., 2010; Szczepaniak et al., 2016).

P was the fifth most absorbed nutrient (Figure 1) and transported (data not shown), the third most used (Figure 2) and accumulated (Figure 3 ) in the PA of maize plants. The liming associated to the fertilization provided the supply of $\mathrm{P}$ to the evaluated plants due to the increase of the $\mathrm{pH}$ of the soils (Table 3), making it more available in the solution of the soils facilitating the absorption of the same by the plants (Opala, 2017; Cunha et al., 2018a, b). The absorption of this nutrient, according to Tomaz et al. (2009), depends on the morphological and physiological characteristics of the roots, however, their importance in the absorption process depends on the root access to the nutrient. When there is no limitation on the arrival of the ion at the root surface, the physiological factors are more important than the morphological ones regarding nutrient absorption (Delhaize et al., 2007; Balemi \& Negisho, 2012).

Al was the least absorbed (Figure 1), transported (data not shown) and accumulated (Figure 3) by maize plants. However, this element was the most used (Figure 2) for TDW production (Table 2). For this reason, the use efficiency index is not suitable/indicated for Al, since TDW production is considered to calculate it (Table 2) and this rises with liming in relation to total $\mathrm{Al}$ content in the plant (low levels found mainly in the shoot), meaning this index may not accurately reflect reality. The lower UE of N, K, Ca and P (Figure 2), primarily by maize plants, may be related to their higher absorption (Fernandes \& Soratto, 2013; Zoca et al., 2014) by these crops, since, according to Silva et al. (2002), as plant nutrient concentration rises, the EU index declines due to the growing nutrient accumulation, which is proportionally higher than the plant DW.

\subsection{Aluminum $\times$ Absorption, Transport, Use and Nutrient Accumulation in Maize Plants}

The absorption, transport, use and subsequent nutrient accumulation by maize plants was not influenced directly by the aluminum present in both the solid (Table 3) and liquid phase (Table 4) in two of the five soils. This behavior was observed in AC9 and RS soils, where in treatments without lime, plants exhibited good nutrient use (Figures 1, 2 and 3). This occurred even at low $\mathrm{pH}$ values and high $\mathrm{Al}^{3+}$ content in the solid phase (Table 3), with the exception of $\mathrm{PE}, \mathrm{BR}$ and $\mathrm{CB}$ soils, where the presence of $\mathrm{Al}^{3+}$ in the solution had a direct influence on nutrient dynamics, evidenced by the low amounts absorbed, transported (data not shown), used and accumulated by plants cultivated in these soils compared to those grown in AC9 and RS. However, the application of lime doses, particularly the first two (25 and 50\% of $\mathrm{H}+\mathrm{Al})$, enhanced the use of all the nutrients available in the solution by the plants cultivated in all the soils (Figures 1, 2 and 3).

The non-influence of $\mathrm{Al}$ on the dynamics of the nutrients available in the present study may be directly related to the rise in basic cations (primarily $\mathrm{Ca}^{2+}$ and $\mathrm{Mg}^{2+}$ ) and the sum of bases in both the liquid and solid phase, as well as the other nutrients with an increase in lime doses in all the soils (Tables 3 and 4 ). When the cation and sum of bases concentrations are higher than those of $\mathrm{Al}$ and the sum of toxic aluminum species in the soil solution (A $\Sigma$ FTAl), the presence of this element may cause little or no harm to plants. This interpretation is corroborated by the results obtained in plants grown in AC9 and RS soils (Figures 1, 2 and 3) and by studies conducted by Caires et al. (2013), Rutkowska et al. (2015) and Cunha et al. (2018a, 2018b). In PE, BR and CB soils, $\mathrm{Ca}^{2+}, \mathrm{Mg}^{2+}$ concentration and sum of bases exceeded that of $\mathrm{Al}^{3+}$ in the soil solution, primarily in treatments without lime (Table 4). In these conditions, $\mathrm{Al}^{3+}$ is not expected to be toxic to plants or interfere in the dynamics of nutrients in plants grown in these soils. However, $\mathrm{Al}^{3+}$ compromised root growth in the plants assessed (data not shown), as well as nutrient absorption (Figures 1b, 1d and 1e, respectively), transport (data not shown), use (Figures 2b, 2d and 2e, respectively) and subsequent accumulation (Figures 3b, 3d and 3e, respectively) of nutrients in the tissues of plants cultivated in these soils, particularly in treatments without lime. This interference may be explained by the high concentration of toxic $\mathrm{Al}^{3+}$ species and A $\mathrm{FTAl}$ in the solution of these soils, far above (except in the CB soil) the critical values $\left(24-27 \mu \mathrm{mol} \mathrm{L}^{-1}\right.$ ) that Diatloff et al. (1998) consider toxic. In the CB soil, although the AEFTAl was lower than the aforementioned critical threshold, the presence of $\mathrm{Al}$ and its toxic species compromised plant development and nutrient use (Figures 1,2 and 3). 
Table 4. Chemical composition and toxic Al species activity in the soil solution

\begin{tabular}{|c|c|c|c|c|c|c|c|c|c|c|c|c|c|c|}
\hline \multirow{2}{*}{ Soil $^{(1)}$} & \multirow{2}{*}{$\mathbf{H}^{(2)}$} & \multirow{2}{*}{ D. C..$^{(3)}$} & \multicolumn{8}{|c|}{ Composition of the Soil Solution } & \multicolumn{4}{|c|}{ AETAI $^{(6)}$ in the Soil Solution } \\
\hline & & & $\mathrm{Ca}^{2+}$ & $\mathrm{Mg}^{2+}$ & $\mathbf{K}^{+}$ & $\mathrm{Na}^{+}$ & $\mathbf{S}^{(4)}$ & $\mathrm{Al}^{3+}$ & $\mathbf{P}$ & $\mathbf{m} \times$ cations $^{(5)}$ & $\mathrm{Al}^{3+}$ & $\mathrm{AlOH}^{2+}$ & $\mathrm{Al}(\mathrm{OH})_{2}{ }^{+}$ & ${\text {A } \Sigma \text { FTAl }^{(7)}}$ \\
\hline & & & 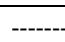 & ------ & $-\mathrm{mmc}$ & $\mathrm{L}^{-1}-\cdots$ & 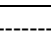 & ------- & $m g L^{-1}$ & $\%$ & ----- & 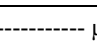 & nol L ${ }^{-1}$ & 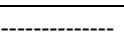 \\
\hline \multirow{4}{*}{ AC9 } & \multirow{4}{*}{$\mathrm{Bt}_{2}$} & 0 & 0.99 & 0.33 & 0.12 & 0 & 1.4 & 0.013 & 0.09 & 1.0 & 7.93 & 2.3 & 0.4 & 10.63 \\
\hline & & 0.25 & 0.90 & 0.36 & 0.13 & 0 & 1.3 & 0.011 & 0.11 & 0.8 & 2.31 & 3.4 & 3.2 & 8.91 \\
\hline & & 0.5 & 0.90 & 0.40 & 0.10 & 0 & 0.9 & 0.007 & 0.09 & 0.4 & 0.91 & 2.0 & 2.7 & 5.61 \\
\hline & & 1 & 0.89 & 0.48 & 0.11 & 0 & 0.8 & 0.006 & 0.24 & 0.2 & 0.24 & 1.0 & 2.6 & 3.84 \\
\hline \multirow{4}{*}{ PE } & \multirow{4}{*}{$\mathrm{Bt}_{2}$} & 0 & 0.19 & 0.38 & 0.34 & 0.01 & 0.8 & 0.048 & 0.13 & 6.6 & 33.4 & 7.7 & 1.0 & 42.1 \\
\hline & & 0.25 & 1.10 & 1.27 & 0.38 & 0.01 & 0.8 & 0.013 & 0.19 & 1.7 & 6.0 & 2.9 & 0.9 & 9.8 \\
\hline & & 0.5 & 0.93 & 1.06 & 0.24 & 0.01 & 0.9 & 0.005 & 0.35 & 0.8 & 0.8 & 1.0 & 0.9 & 2.7 \\
\hline & & 1 & 1.75 & 1.84 & 0.20 & 0 & 1.1 & 0.001 & 0.36 & 0.2 & 0.0 & 0.1 & 0.2 & 0.3 \\
\hline \multirow{4}{*}{$\mathrm{RS}$} & \multirow{4}{*}{$\mathrm{Bt}_{3}$} & 0 & 0.91 & 0.42 & 0.15 & 0 & 0.8 & 0.008 & 0.14 & 0.9 & 2.48 & 2.1 & 1.0 & 5.66 \\
\hline & & 0.25 & 1.41 & 0.69 & 0.17 & 0 & 0.7 & 0.002 & 0.13 & 0.4 & 0.44 & 0.7 & 0.7 & 1.84 \\
\hline & & 0.5 & 1.65 & 0.80 & 0.10 & 0 & 0.8 & 0.002 & 0.13 & 0.4 & 0.10 & 0.4 & 1.0 & 1.5 \\
\hline & & 1 & 2.84 & 2.07 & 0.21 & 0 & 1.4 & 0.000 & 0.19 & 0.1 & 0.00 & 0.0 & 0.1 & 0.1 \\
\hline \multirow{4}{*}{$\mathrm{BR}$} & \multirow{4}{*}{$\mathrm{B}_{\mathrm{i}}$} & 0 & 0.12 & 0.08 & 0.16 & 0 & 0.3 & 0.043 & 0.12 & 13.9 & 20.21 & 10.3 & 3.0 & 33.51 \\
\hline & & 0.25 & 0.60 & 0.35 & 0.13 & 0 & 0.6 & 0.011 & 0.10 & 1.4 & 3.57 & 5.1 & 4.8 & 13.47 \\
\hline & & 0.5 & 0.63 & 0.50 & 0.11 & 0 & 0.6 & 0.005 & 0.17 & 0.5 & 0.25 & 1.0 & 2.3 & 3.55 \\
\hline & & 1 & 1.71 & 1.60 & 0.10 & 0 & 1.0 & 0.003 & 0.23 & 0.1 & 0.03 & 0.3 & 1.3 & 1.63 \\
\hline \multirow{4}{*}{$\mathrm{CB}$} & \multirow{4}{*}{$\mathrm{Bw}_{3}$} & 0 & 0.10 & 0.03 & 0.25 & 0 & 0.3 & 0.013 & 0.06 & 4.0 & 6.50 & 2.9 & 0.7 & 10.1 \\
\hline & & 0.25 & 1.16 & 0.50 & 0.29 & 0 & 0.6 & 0.005 & 0.25 & 0.8 & 1.95 & 3.6 & 4.4 & 9.95 \\
\hline & & 0.5 & 1.17 & 0.72 & 0.20 & 0 & 0.7 & 0.004 & 0.17 & 0.3 & 0.16 & 0.7 & 1.8 & 2.66 \\
\hline & & 1 & 2.52 & 2.26 & 0.28 & 0 & 1.2 & 0.002 & 0.19 & 0.1 & 0.02 & 0.2 & 0.8 & 1.02 \\
\hline
\end{tabular}

Note. ${ }^{(1)}$ AC9: collected in Tarauacá, Acre state; Profile 9; PE: collected in Ipojuca, Pernambuco state; RS: collected in Rosário do Sul, Rio Grande do Sul state; BR: collected in Bom Retiro, Santa Catarina (SC) state; CB: collected in Curitibanos, SC; ${ }^{(2)}$ Soil collection layer; ${ }^{(3)}$ lime doses applied to the soils; ${ }^{(4)}$ Sum of the bases; ${ }^{(5)}$ Aluminum fraction in relation to all the cations in the soil solution; ${ }^{(6)}$ Activity of toxic Al species in the soil solution; ${ }^{(7)}$ Sum of toxic Alspecies in the soil solution.

Cunha et al. (2018b) assessed chemical species activity of all the cations and anions present in the soil solutions

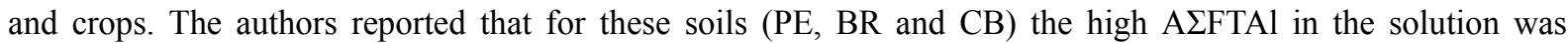
controlled by the amorphous polymers from hydroxy-interlayered vermiculite (HIV) and hydroxy-interlayered smectite (HIS), which maintained the balance of this chemical species of $\mathrm{Al}^{3+}$ in the solution and its toxic potential to plants, as reported by Dahlgren and Walker (1993), even with high basic cation activity in the soil solutions (Table 3).

The use of these nutrients by plants with a rise in lime doses is directly related to the increased sum of bases in

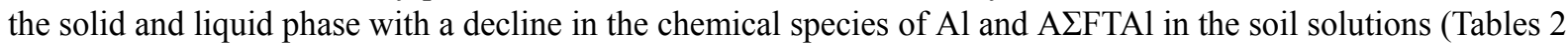
and 3). This use is particarly evident in the first two lime doses (Figures 1, 2 and 3), possibly because of the rise in basic cation concentration and their activity (Cunha et al., 2018b) in the solution that exceeds the concentration of $\mathrm{Al}$ species and activity of this element in the solution (Table 3).

It is important to underscore that $\mathrm{Al}$ inactivation in the soil solution may also be related to the levels available and P concentration in the soil solution studied.In field conditions, Nolla and Anghinoni (2006) observed that high phosphate levels displaced organic exchange anions via the mass action mechanism in typical dystrophic Red Latosol $\left(\mathrm{pH}=4.0\right.$ and $\left.\mathrm{Al}=3.22 \mathrm{cmol}_{\mathrm{c}} \mathrm{kg}^{-1}\right)$, thereby reducing the $\mathrm{Al}$ in solution by forming organic complexes with Al.Nolla et al. (2013) also observed a decline in Al toxicity with P application, which provided better soybean root development. The authors concluded that Al phosphate formed from the release of organic acids capable of complexing the Al present in the soil solution under high acidity conditions. Ernani et al. (2000) assessed the lime/phosphate ratio and found that the highest $\mathrm{P}$ doses in liming did not affect maize yield. For these reasons, levels of this element available in soils are jointly indicated as the criterion for calculating lime requirements (CQFSRS/SC, 2016). These results are supported by the studies developed by Rutkowska et al. (2015), De Conti et al. (2017), and Cunha et al. (2018a, 2018b).

Another important point to consider regarding the manifestation or not of $\mathrm{Al}$ toxicity to plants is the exchangeable $\mathrm{Ca} / \mathrm{Al}$ ratio of soils, in addition to chemical composition assessment, chemical spetiation and the activity of toxic aluminum species in solution. In AC9 and RS soils in which little or no response to liming occurred, the ratio between these two exchangeable cations after cultivation was 1.32 and 1.28 , respectively. In 
other words, in this condition, $\mathrm{Al}$ would not be toxic to plants, because they were below the critical limit $(0.42$ and 0.48) reported by Smyth and Cravo (1992) and Gama and Kiehl (1999). For PE, BR and CB soils, the lowest lime dose $(25 \%$ of $\mathrm{H}+\mathrm{Al})$ was enough to make the $\mathrm{Ca} / \mathrm{Al}$ ratio greater than or equal to the critical level proposed by the aforementioned authors. Given the results of this study, lime application increases nutrient availability in the soil solution, in addition to reducing exchangeable Al levels, concentration and activity, favoring its absorption, transport, use and accumulation, providing good nutrition to the plants under study. However, it is important to underscore that the efficiency indices and nutrient accumulation were higher, primarily with the use of the first two lime doses ( 25 and $50 \%$ of $\mathrm{H}+\mathrm{Al})$. This occurred even though the exchangeable $\mathrm{Al}$ levels in most of the soils were above $4 \mathrm{cmol}_{\mathrm{c}} \mathrm{kg}^{-1}$ and saturation was more than than $30 \%$, indicative of aluminum toxicity. This seems to suggest that at these and higher doses, $\mathrm{Al}-\mathrm{KCl}$ may no longer exert a toxic effec. Thus, the exchangeable Al method should be viewed with caution and in conjunction with the other nutrients, since their levels are used to calculate the degree of Al saturation and liming, thereby overestimating lime doses and the cost of implementing crops, with no return on plant yield.

\section{Conclusions}

The Al-KCl did not affect nutrient absorption, transport, use and accumulation in the tissues of maize plants cultivated in AC9 and RS soils. However, it did interfere in plants grown in PE, BR and CB soils. The plants made good use of the nutrients dissolved in solution with the first two doses ( 25 and $50 \%$ of $\mathrm{H}+\mathrm{Al})$.

The absence of $\mathrm{Al}$ toxicity is related to an increase in concentration, basic cation activity and $\mathrm{P}$ availability in the soil solution, which, taken together, decreased $\mathrm{Al}$ activity in the solution, inactivating it and making the element non-toxic to the maize plants.

In soils with a high $\mathrm{Ca} / \mathrm{Al}$ or $\mathrm{Ca}+\mathrm{Mg} / \mathrm{Al}$ ratio ( $\mathrm{AC} 9$ and $\mathrm{RS}$, respectively), $\mathrm{Al}$ activity in the solution is low, even when absolute $\mathrm{Al}-\mathrm{KCl}$ levels are high, and may not be toxic to maize plants. On the other hand, in soils (PE, BR and $\mathrm{CB}$ ) where this ratio is lower than that of $\mathrm{Al}$ in solution, $\mathrm{Al}$ activity is high and toxic to maize plants.

\section{References}

Adisu, T., Wogi, L., \& Feyisa, T. (2019). Soybean (Glycine max L.) response to lime and vermicompost amelioration of acidic Nitosols of Assosa, North Western Ethiopia. International Journal of Plant \$ Soil Science, 27, 1-18. https://doi.org/10.9734/ijpss/2019/v27i230072

Amaral, J. F. T., Martinez, H. E. P., Laviola, B. G., Filho, E. I. F., \& Cruz, C. D. (2011). Eficiência de utilização de nutrientes por cultivares de cafeeiro. Ciência Rural, 41, 621-629. https://doi.org/10.1590/S0103-84782 011005000027

Balemi, T., \& Negisho, K. (2012). Management of soil phosphorus and plant adaptation mechanisms to phosphorus stress for sustainable crop production: a review. Journal of Soil Science and Plant Nutrition, 12, 547-561. https://doi.org/10.4067/S0718-95162012005000015

Bojórquez-Quintal, E., Escalante-Magaña, C., Echevarria-Machado, I., \& Martinez-Estévez, M. (2017). Aluminum, a friend or foe of higher plants in acid soils. Frontier in Plant Science, 8, 1-18. https://doi.org/10.3389/fpls.2017.01767

Caires, E. F. (2013). Correção da acidez do solo em sistema de plantio direto. Informações Agronômicas, 141, $1-13$.

Caires, E. F., \& Fonseca, A. F. (2000). Absorção de nutrientes pela soja cultivada no sistema de plantio direto em função da calagem na superfície. Bragantia, 59, 213-220. https://doi.org/10.1590/S0006-87052000000 200013

Caires, E. F., Barth, G., Garbuio, F. J., \& Churka, S. (2008). Soil acidity and soybean performance under no-till. Scientia Agricola, 65, 532-540. https://doi.org/10.1590/S0103-90162008000500013

Carvalho, R. F. (2012). Efficiency of maize cultivars in the absorption and use of nitrogen in a greenhouse environment. Semina: Ciências Agrárias, 33, 2125-2136.

CQFS-RS/SC. (2004). Manual de adubação e calagem para os Estados do Rio Grande do Sul e de Santa Catarina. Porto Alegre (p. 400). Sociedade Brasileira de Ciência do Solo-Núcleo Regional Sul, UFRGS.

CQFS-RS/SC. (2016). Manual de calagem e adubação para os Estados do Rio Grande do Sul e de Santa Catarina (11th ed., p. 376). Sociedade Brasileira de Ciência do Solo-Núcleo Regional Sul. 
Cunha, G. O. M., Almeida, J. A., Barboza, B. B. (2014). Relação entre o alumínio extraível com KCl e oxalato de amônio e a mineralogia da fração argila, em solos ácidos brasileiros. Revista Brasileira de Ciência do Solo, 38, 1387-1401. https://doi.org/10.1590/S0100-06832014000500004

Cunha, G. O. M., Almeida, J. A., Ernani, P. R., Pereira, E. R., Skoronski, E., Lourenço, L. S., \& Brunetto, G. (2018a). Chemical species and aluminum concentration in the solution of acid soils cultivated with soybean and corn under liming. Revista Brasileira de Ciência do Solo, 42, 1-16. https://doi.org/10.1590/ 18069657 rbcs20170406

Cunha, G. O. M., Almeida, J. A., Testoni, S., \& arboza, B. B. (2015). Formas de alumínio em solos ácidos brasileiros com teores excepcionalmente altos de $\mathrm{Al}^{3+}$ extraível com KCl. Revista Brasileira de Ciência do Solo, 39, 1362-1377. https://doi.org/10.1590/01000683rbcs20150017

Cunha, G. O.M., Almeida, J. A., Ernani, P. R., Pereira, E. R., \& Brunetto, G. (2018b). Composition, chemical speciation and activity of ions in the solution of Brazilian acid soils. Revista Brasileira de Ciências Agrárias, 13, 1-10. https://doi.org/10.5039/agraria.v13i3a5542

Dahlgren, R. A., \& Walker, W. J. (1993). Aluminum release rates from selected Spodosol Bs horizons: Effect of $\mathrm{pH}$ and solid-phase aluminum pools. Geochimica et Cosmochimica Acta, 57, 57-66. https://doi.org/ 10.1016/0016-7037(93)90468-C

De Conti, L., Ceretta, C. A., Couto, R. R., Ferreira, P. A. A., Silva, L. O. S., Piccin, R., ... Brunetto, G. (2017). Aluminum species and activity in sand soil solution with pig slurry addition. Pesquisa Agropecuária Brasileira, 52, 914-922. https://doi.org/10.1590/s0100-204x2017001000011

De Souza, L. T., Cambraia, J., Ribeiro, C., De Oliveira, J. A., \& Da Silva, L. C. (2016). Effects of aluminum on the elongation and external morphology of root tips in two maize genotypes. Bragantia, 75, 19-28. https://doi.org/10.1590/1678-4499.142

Delhaize, E., Gruber, B. D., \& Ryan, P. R. (2007). The roles of organic anion permeases in aluminum resistance and mineral nutrition. Federation of European Biochemical Societies Letter, 581, 2255-2262. https://doi.org/10.1016/j.febslet.2007.03.057

Diatloff, E., Harper, S. M., Asher, C., \& Smith, F. W. (1998). Effects of humic and fulvic acids on the rhizotoxicity of lanthanum and aluminum to corn. Australian Journal of Soil Research, 36, 913-919. https://doi.org/10.1071/S98018

Ebeling, A. G., Anjos, L. H. C., Perez, D. V., Pereira, M. G., \& Valladares, G. S. (2008). Relação entre a acidez e outros atributos químicos em solos com teores elevados de matéria orgânica. Bragantia, 67, 429-439. https://doi.org/10.1590/S0006-87052008000200019

EMBRAPA (Empresa Brasileira de Pesquisa Agropecuária). (2011a). Centro Nacional de Pesquisa de Solos. Sistema Brasileiro de Classificação de Solo. Projeto-Solos Alíticos (p. 63). Pernambuco: Recife.

EMBRAPA (Empresa Brasileira de Pesquisa Agropecuária). (2011b). Centro Nacional de Pesquisas de Solos. Manual de métodos de análises de solos (2nd ed., p. 230). Rio de Janeiro: RJ.

EMBRAPA (Empresa Brasileira de Pesquisa Agropecuária). (2013a). Centro Nacional de Pesquisa de Solos. In L. H. C. Anjos, L. M. Silva, P. G. S. Wadt, J. F. Lumbreras, \& M. G. Pereira (Eds.), Solos sedimentares em sistemas amazônicos-potencialidades e demandas de pesquisas (p. 204). Guia de Campo.

EMBRAPA (Empresa Brasileira de Pesquisa Agropecuária). (2013b). Centro Nacional de Pesquisa de Solos. Sistema Brasileiro de Classificação de Solo. Revisada e Ampliada (3rd ed, p. 353). Brasília: DF.

Ernani, P. R., Nascimento, J. A. L., Campos, M. L., \& Camillo, R. J. (2000). Influência da combinação de fósforo e calcário no rendimento de milho. Revista Brasileira de Ciência do Solo, 24, 537-544. https://doi.org/10.1590/S0100-06832000000300007

Ertifik, H., \& Zengin, M. (2017). Response of maize for grain to potassium and magnesium fertilizers in soils with high lime contents. Journal of Plant Nutrition, 40, 93-103. https://doi.org/10.1080/01904167. 2016.1201493

Fageria, N. K., \& Moreira, A. (2011). The role of mineral nutrition on root growth of crop plants. Advances in Agronomy, 110, 251-331. https://doi.org/10.1016/B978-0-12-385531-2.00004-9

Fernandes, A. M., \& Soratto, R. P. (2013). Eficiência de utilização de nutrientes por cultivares de batata. Bioscience Journal, 29, 91-100. 
Ferreira, D. F. (2014). Sisvar: A guide for its Bootstrap procedures in multiple comparisons. Ciência e Agrotecnologia, 38, 109-112. https://doi.org/10.1590/S1413-70542014000200001

Gama, J. R. N. F., \& Kiehl, J. C. (1999), Influência do alumínio de um Podzólico Vermelho-Amarelo do Estado do Acre no crescimento de plantas. Revista Brasileira de Ciência do Solo, 23, 475-482. https://doi.org/10.1590/S0100-06831999000200030

Gransee, A., \& Führs, H. (2012). Magnesium mobility in soils as a challenge for soil and plant analysis, magnesium fertilization and root uptake under adverse growth conditions. Plant and Soil, 36, 5-21. https://doi.org/10.1007/s11104-012-1567-y

Gustaffson, J. P. (2016). Visual Minteq, 3.1. Stockholm: KTH, Department of Land and Water Resources Engineering. Retrieved from https://vminteq.lwr.kth.se/download

Hepler, P. K. (2005). Calcium: A central regulator of plant growth and development. Plant Cell, 1, $2142-2155$. https://doi.org/10.1105/tpc.105.032508

Horn, D., Ernani, P. R., Sangoi, L., Schweitzer, C., \& Cassol, P. C. (2006). Parâmetros cinéticos e morfológicos da absorção de nutrientes em cultivares de milho com variabilidade genética contrastante. Revista Brasileira de Ciência do Solo, 30, 77-85. https://doi.org/10.1590/S0100-06832006000100009

Horst, W. J., Wang, Y. X., \& Eticha, D. (2010). The role of the root apoplast in aluminium-induced inhibition of root elongation and in aluminium resistance of plants: A review. Annals of Botany, 106, 185-197. https://doi.org/10.1093/aob/mcq053

Jezek, M., Geilfus, C. M., Bayer, A., \& Mühling, K. H. (2015). Photosynthetic capacity, nutrient status, and growth of maize (Zea mays L.) upon $\mathrm{MgSO}_{4}$ leaf-application. Frontiers in Plant Science, 5, 781. https://doi.org/10.3389/fpls.2014.00781

Joris, H. A. W., Caires, E. F., Bini, A. R., Scharr, D. A., \& Haliski, A. (2013). Effects of soil acidity and water stress on corn and soybean performance under a no-till system. Plant and Soil, 365, 409-424. https://doi.org/10.1007/s11104-012-1413-2

Junio, G. R. Z., Sampaio, R. A., Nascimento, A. L., Santos, G. B., Santos, L. D. T., \& Fernandes, L. A. (2013). Produtividade de milho adubado com composto de esgoto e fosfato natural de Gafsa. Revista Brasileira de Engenharia Agrícola e Ambiental, 17, 706-712. https://doi.org/10.1590/S1415-43662013000700003

Júnior, A. B. A., Nascimento, C. W. A., \& Barros, F. M. R. (2015). Acidez potencial estimada pelo método do pH SMP em solo do Estado da Paraíba. Revista Brasileira de Ciência do Solo, 39, 767-773. https://doi.org/ 10.1590/01000683rbcs20140307

Kaminski, J., Gatiboni, L. C., Rheinheimer, D. S., Martins, J. R., Santos, E. J. S., \& Tissot, C. A. (2002). Estimativa da acidez potencial em solos e sua implicação no cálculo da necessidade de calcário. Revista Brasileira de Ciência do Solo, 26, 1107-1113. https://doi.org/10.1590/S0100-06832002000400029

Laviola, B. G., \& Dias, L. A. S. (2008). Teor e acúmulo de nutrientes em folhas e frutos de pinhão-manso. Revista Brasileira de Ciência do Solo, 32, 1969-1975.

Li, B., Mckeand, S. E., \& Allen, H. L. (1991). Genetic variation in nitrogen use efficiency of loblolly pine seedlings. Forest Science, 37, 613-626.

Liu, T., Huang, R., Cai, T., Han, R., \& Dong, S. (2017). Optimum leaf removal increases nitrogen accumulation in Kernels of maize grown at high density. Scientific Reports, 7, 39601. https://doi.org/10.1038/srep39601

Maluf, H. J. G. M., Silva, C. A., Curi, N., Norton, L. D., \& Rosa, S. D. (2018). Adsorption and availability of phosphorus in response to humic acid rates in soils limed with $\mathrm{CaCO}_{3}$ or $\mathrm{MgCO}_{3}$. Ciência e Agrotecnologia, 42, 7-20. https://doi.org/10.1590/1413-70542018421014518

Martins, K, V., Dourado-Neto, D., Reichardt, K., Favarin, J. L., Sartori, F. F., Felisberto, G., \& Mello, S. C. (2017). Maize dry matter production and macronutrient extraction model as a new approach for fertilizer rate estimation. Anais da Academia Brasileira de Ciências, 89, 705-716. https://doi.org/10.1590/ 0001-3765201720160525

Miller, R. O. (1998). Microwave digestion of plant tissue in a closed vessel. In Y. P. Kalra (Ed.), Handbook of reference Methods for plant analysis (2nd ed., pp. 69-73). CRC Press Inc. Boca Raton. https://doi.org/10.1201/9781420049398.ch8 
Murphy, J., \& Riley, J. P. (1962). A modified single solution method for the determination of phosphate in natural waters. Analytica Chimica Acta, 27, 31-36.

Nolla, A., \& Anghinoni, I. (2006). Atividade e especiação química na solução afetadas pela adição de fósforo em Latossolo sob plantio direto em diferentes condições de acidez. Revista Brasileira de Ciência do Solo, 30, 955-963. https://doi.org/10.1590/S0100-06832006000600005

Nolla, A., Anghinoni, I., Silva, T. R. B., \& Silva, M. A. G. (2013). Lime-phosphate relation and soybean growth in an Oxisol from no-tillage system. Journal of Food Agriculture Environment, 11, 294-298.

Opala, P. A. (2017). Influence of lime and phosphorus application rates on growth of maize in acid soil. Advances in Agriculture, 1-5. https://doi.org/10.1155/2017/7083206

Rastija, D., Zebec, V., \& Rastija, M. (2014). Impacts of liming with dolomite on soil pH and phosphorus and potassium availabilities. Villach, 63, 1-4.

Riedell, W, E. (2010). Mineral-nutrient synergism and dilution response to nitrogen fertilizer in field-grown maize. Journal Plant Nutrition and Soil Science, 173, 869-874. https://doi.org/10.1002/jpln.200900218

Rutkowska, B., Szulc, W., Hoch, M., \& Spychaj-Fabisiak, E. (2015). Forms of Al in soil and soil solution in a long-term fertilizer application experiment. Soil and Use Management, 31, 114-120. https://doi.org/10.1111/ sum. 12150

Sade, H., Meriga, B., Surapu, V., Gadi, J., Sunita, M. S. L., Suravajhala, P., \& Kishor, P. B. K. (2016). Toxicity and tolerance of aluminum in plants: Tailoring plants to suit to acids. Biometals, 29, 187-210. https://doi.org/10.1007/s10534-016-9910-z

Salvador, J. T., Carvalho, T. C., \& Lucchesi, L. A. C. (2011). Relações cálcio e magnésio presentes no solo e teores foliares de macronutrientes. Revista Acadêmica: Ciências Agrárias e Ambientais, 9, $27-32$. https://doi.org/10.7213/cienciaanimal.v9i1.11060

Sathiyavani, E., Prabaharan, N. K., \& Surendar, K. K. (2017). Role of mineral nutrition on root growth of crops plants-A review. International Journal of Current Microbiology and Applied Sciences, 6, 2810-2837. https://doi.org/10.20546/ijcmas.2017.604.324

Siddiqi, M. Y., \& Glass, A. D. M. (1981). Utilization index: A modified approach to the estimation and comparison of nutrient utilization efficiency in plants. Journal of Plant Nutrition, 4, $289-302$. https://doi.org/10.1080/01904168109362919

Silva, F. C. da. (2009). Manual de análises químicas de solos, plantas e fertilizantes (2nd ed., p. 627). Brasília: Embrapa Informação Tecnológica; Rio de Janeiro: Embrapa Solos.

Silva, S. R., Barros, N. F., Novais, R. F., \& Pereira, P. R. G. (2002). Eficiência nutricional de potássio e crescimento de eucalipto influenciados pela compactação do solo. Revista Brasileira de Ciência do Solo, 26, 1001-1010. https://doi.org/10.1590/S0100-06832002000400018

Smyth, T. J., \& Cravo, M. S. (1992). Aluminum and calcium constraints to continuous crop production in a Brazilian amazon Oxisol. Agronomy Journal, 84, 843-850. https://doi.org/10.2134/agronj1992.0002196200 $8400050016 x$

Swiader. J. M., Chyan, Y., \& Freiji, F. G. (1994). Genotypic differences in nitrate uptake and utilization efficiency in pumpkin hybrids. Journal of Plant Nutrition, 17, 1687-1699. https://doi.org/10.1080/019041 69409364840

Szczepaniak, W., Grzebisz, W., Potarzycki, Lukowiak, R., \& Przygocka-Cyna, K. (2016). The magnesium and calcium mineral status of maize at physiological maturity as a tool for an evaluation of yield forming conditions. Journal of Elementology, 21, 881-897. https://doi.org/10.5601/jelem.2015.20.4.901

Tandzi, L. N., Mutengwa, C. S., Ngonkeu, L. M., \& Gracen, V. (2018). Breeding maize for tolerance to acid soils: A review. Agronomy, 8, 1-21. https://doi.org/10.3390/agronomy8060084

Tedesco, M. J., Gianello, C., Bissani, C. A., Bohnen, H., \& Volkweiss, S. J. (1995). Análise de solos, plantas e outros materiais. Boletim Técnico de Solo 5 (2nd ed., p. 170). Porto Alegre: UFRGS.

Tomaz, M. A., Martinez, H. E. P., Cruz, C. D., Freitas, R. S., Pereira, A. A., \& Sakiyama, N. S. (2009). Eficiência relacionada à absorção e utilização de nitrogênio, fósforo e enxofre, em plantas de cafeeiros enxertadas, cultivadas em vasos. Ciência e Agrotecnologia, 33, 993-1001. https://doi.org/10.1590/S1413-70542009 000400008 
Wadt, P. G. S. (2002). Manejo de solos ácidos do Estado do Acre (Documentos 79, p. 31). Rio Branco: Empresa Brasileira de Pesquisa Agropecuária-Embrapa/Acre.

Yang, S., Zhang, Z., Cong, L., Wang, X., \& Shi, S. (2013). Effect of fulvic acid on the phosphorus availability in acid soil. Journal of Soil Science and Plant Nutrition, 13, 526-533. https://doi.org/10.4067/S0718-95162013 005000041

Zoca, S. M., Penn, C. J., Rosolem, C. A., \& Alves, A. R. (2014). Coffee processing residues as a soil potassium amendment. International Journal of Recycling of Organic Waste in Agriculture, 3, 155-165. https://doi.org/ 10.1007/s40093-014-0078-7

\section{Copyrights}

Copyright for this article is retained by the author(s), with first publication rights granted to the journal.

This is an open-access article distributed under the terms and conditions of the Creative Commons Attribution license (http://creativecommons.org/licenses/by/4.0/). 